\title{
SOOTY TERN BEHAVIOR
}

By

JAMES JAY DINSMORE

A DISSERTATION PRESENTED TO THE GRADUATE COUNCIL OF THE UNIVERSITY OF FLORIDA

IN PARTLLL FULFILLMENT OF THE REQUIREMENTS FOR THE DEGREE OF DOCTOR OF PHILOSOPHY

UNIVERSITY OF FLORIDA

1970 


\section{ACKITCVIEDTEVTS}

I rave bereitted great?y Irom the counsel and interest of rany individuals. The adrice and encouragement of Dr. Oliver i. hustin, ir. have aided me throughout this tiork, both in the field and in preparing a written report. Ir. Wiliam 3. iobertson, Jr. continually provided me with information on Socty Tems and also arranged Icr my stay on the Dry Tortugas. The comments ard criticisis of Dns. George W. Comwelz, Frank G. Nordzie, Thanas J. Vialker, and S. David Webo hatre pointed out many teaknesses in my work and themby have best of great help to ne. I also have profited from discussions on Sootir Terrs vith Brian Harrington, Robert W. Ýreslane, John C. Orden, D. Gienn E. Woolfenden, and others, especiaily man members of banding parties to the Torbugas. Personnel at Fort jefferson Netional Honment and Evergledes Nationel Part were especieliy heipful in providing a piace for me to live at iort jefferson and tiren raking that living enjoyable. Dr. Gary D. Schreli genorously gave me access to his unpiclished data on Sony Terr flifit speads. The Florida Stato Yuseur prorided a bogt to use at Font deirereon. Tyo grants from the Frank a. Chamar Fund, Amarican ifuseum of "idtura? History, and a Louis Agassiz Fuertes Research Enant from the Tilsson Ornithologicel Society heiped finarce the fiteld work. A University of Florida fracuate School Failowship made it possible for me to spond

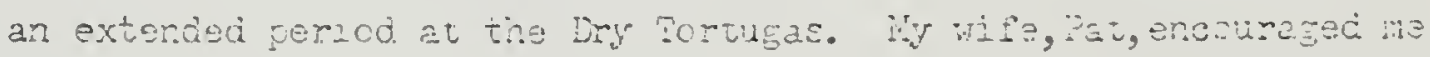
througrout the study and typec the sinat dintis of this dissentetion. To 211 these individuals art oreanations, z am guteful. 
ACKNGEEDGEITS. . . . . . . . . . . . .

LIST OF FIGUPSS. . . . . . . . . . . . . •

INTRODUCTIOH . . . . . . . . . . . . .

THS DPY TORTUGAS . . . . . . . . . . . . .

Physical Features . . . . . . . . . . .

Fauna . . . . . . . . . . . . . . .

Cinnate...................

Previous fior. . . . . . . . . . . . . .

METHODS,

BRETEAT ACTIVITES.

Formation of the Colont ............

Acrial Fioking. . . . . . . . . . . •.

First Landina. . . . . . . . . . . . .

Dremlayins Aotivities..............

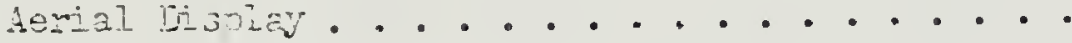

Ground Activities. . . . . . . . . . .

Estailising Territories . . . . . . . . .

Incubation Period . . . . . . . . . . . .

Egs-laving . . . . . . . . . . . . . . . .

Behavior Iuring Incubation . . . . . . .

Attentireness. . . . . . . . . . . . .

Iroping. . . . . . . . . . . . . .

Temerature Regulation . . . . . . . . .

Hest Reites. . . . . . . . . . . . .

Lengtir of ncubation jistis. . . . . . . .

Influence of Veather . . . . . . . . . . .

Fledging Paniod . . . . . . . . . . . .

Hatching...............

hutentiveness. . . . . . . . . . .

Feeding. . . . . . . . . . . . . . .

Frequency of Feadirg.............

Individual Fecognition . . . . . . . . .

Chick Benavior............... 
Other serial Activities................. Tremal Scaring. . . . . . . . . . . . . . Fly-uos. . . . . . . . . . . . . . . . Panics . . . . . . . . . . . . . .

ECOCOGY. . . . . . . . . . . . . . . . . . .

Interactions vith Other Species............

Enenies. . . . . . . . . . . . .

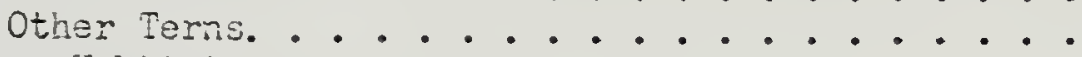

Nesting Faottat. . . . . . . . . . . . . . .

Site Tenacity....................

DISCUSSION • . . . . . . . . . . . . . . . . . .

Behavioral Comparisons. . . . . . . . . . . . .

Sooties as a Pelagic Species. . . . . . . . . . .

LITERATUPE CITED . . . . . . . . . . . . . . . . .

BIOGRAPHCAL SRETCH. . . . . . . . . . . . . . . 


\section{LIST. OF TABLES}

Tabie

Page

1 Activities other than incubating or shading by Souty Terns caring for an egs

2 Sumary of 2.13 dipping flights by Sooty Terns

3 Time of occurrence of flights away from the egs by adult sooty Tems

4 Time of nest relief during incubation

5 Time of feeding of young Sonty Terms

6 Rate of forazing by adult Sooty Terns

7 llest density and success in five 5-yard-square plotis on Bush Key in 1968

8 Some infornation on the breeding biology 0 severai species of terns 


\section{LIST OF FIGUESS}

Figure

Page

I Vao ö Dry Tortugas islarks

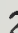

Posture of Sooty Tern in the parade display

3 Activities by adult Sooty Temis during incubation.

4 Letivities by acult sooty Tems during tine first 2 weeks of caring for the chick 


\section{Abstract of Dissertation Presented to the}

Graduate Council of the Jniversty $0 \hat{\mathrm{s}}$ Florida in Pertial Fulfilment of the Reguirements for the Degree of Loctor of Pnilosoning

SOOTY TERY BETAVOR

\section{Sy}

James Jay Iinstore

$$
\text { August, } 1970
$$

Chaiman: Dr, Oliver I. Austin, Jr. Majur Departrent: Zoologe

A 3-jear study of the breeding behavior of Sooty Ierns (Sterna fuscata) ras nade at Bush Fey, Dry Tortijas in the southeastem Guif of ifexice. The results are conpared with the behavior of other terins and the differences discussed, particularly in regare to the peiastc environent the Sooty Term inhab:ts.

Sooty Terns arrive at the Dry Tortugas some 2 nonths beicre eggs are first laid. It first they circle Bush Xey at night only, but eventually land and extend the tine they spend on the eround, arriving earlier in the evening and leaving later in the moming. After the first eggs are laid, plocking subsides. Aeriai display by Sorty Terns consists mainly of the righ flight in when two birde ascend, usually by jexl-nying, circle, and then descend together in a cooriinated glide, Sooty Tewis may have a poorly developed low flight dispiag. On the ground the major display is the parade, similar to that of other Sterna tems. Courtship feeding is rare. Terns often incerfere with pairs attumoting to copuiate.

the single egg is incubated about 29.5 days with the male caring 
for it sonerbat more than the female. The birds ane attentive over 95 per cent of the time, incubating when it is cool, shading when it is hot, and engaging in other activities such ds preening, fighting, and loafing rost comonly when they change between incubating and shaitin. Nest relief uslialy ocolirs in the evening after 24 or 48 hours of care. Dipping, in which adults dip their feet, oili and/or breast feathers in the ccean, ia comon during incibition and may cool the ggg or provide it with needed moisture.

Chicks are ciosely broodec for 4 or 5 days, after which adults seem to recognize them indivioually and spend progressively less time with ther. By the end of the 3 ad week, chicics are alone much of the time except when fed. Adults feed the chick by resurgitetion, soend anout 3.5 hours per foragins trip, and ofter feed a chick several times afier one trip. Haies feed the chick screwhat more than females do. Vocai exchanges befween parent and chici seem most importart in individuai recognition. Cecasionally adults feed a chick cther than their own. Chicks first ily when about 9 weeks old end leave the colony scon after tinat.

The grcurd and arrial displays of spoty lows are similar to thuse of other Stemin terias, escecially the Conmon lern. The rarity of tile Iow flight ard courtship feeding, botis of wich are comon in other terns, may be due to the difierent way Łn which Sooties carry food and the distance they travel to forase.

Sooty Tems have a lovei clutun size, longer perior of development of the chick, and Pirst breed rhen older then most other terns, nany of which feed in marsios and coastul biters. These chamactentstics of Sooty Tern brealing biology are similar to those on may other pelazic 
birds. A distant food supply and high adult survivorship apparently have contributed to these differences from other tems. 


\section{INTEODTCTON}

Sooty Terns (Stema fusgate) vccur worldside in tropical and subtropical waters, breecing mainiy on low isolated islancis (Ashole, 1963). Some colonies mitber in the mizions (Miliey and Parcy, 1950) and the species couid vell be one of the most numerous of the ror.d's birds. This tem ranges cver the open ccean to feed, thus differing from the may terns that feed in coastai waters. Sooties apparently retum to land only during the broeding season. Cther pecularities of Sooty Tem beharior include a nonamial breoding cycle at some Iocalities (Chapin, 1954; Astmole, 1963), and a long rigration by juveniles (30oertson, 2969).

Although the etroingy of several spocies of terms is well knom, no pelagic species of Sterna are adequately studicd. The basic studies of Sooty Tem behavior were made 50 years ago (Watson, 1908; Watcon. and Lashiey, 1915; Iashley, 1915) and certainly need to be urdated. From 1968 thmongh 1970 I studied the oehavior of Sroty Terns at the Iny Toriugas Islance, watching a group of terms throughout the breeding season anci recoraing their behavior at ail. accessible stages. This paper presents basic infornation on the behavior of a tropical Sterna and attompts to relate tise behavion to the species' pelagic habits

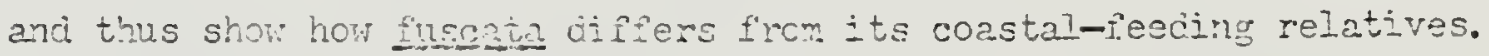




\section{Divisica Features}

The Iry Tortugas presertiv consist of seven mali lom isiands at approximatoly $24039 \%, 82052 \%$, about 79 miles west of fei lest, Florida (Ifgle I). In the past century at least foum other islands

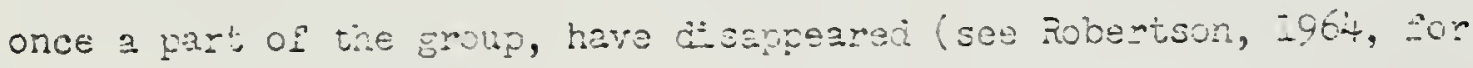
history of eli the Is.ands). The isiands are located on a Iare shallo: bank, Fuch ồ it less then 5 fathons coep, in the scutheastom.

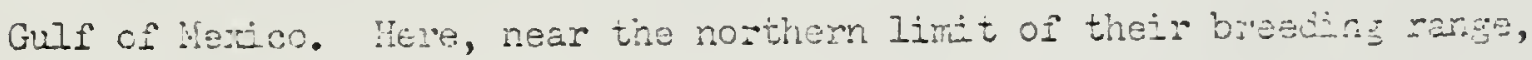
some 80,000 5ooty Tems have nested in reoent vears. The earliest

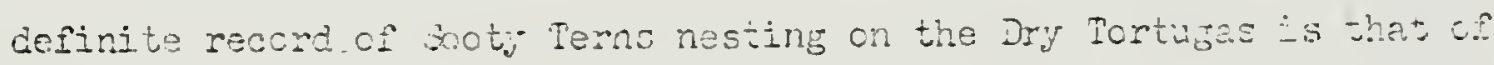
Audubor (1844) who Found them nesting rith Brow liodides (inoiz stolidus) or Bira rey in 1832. Both species continued io nesi a: 3 ird Key uni- ille oarly I930's when it finelly washed aray. The birus tiza? moved to rearby Bush $\mathrm{ke}$, which hes been the major breecing site evar since, aithcugh occasionalij some hare nested or Garden, lonj, and Hospital Zajs.

All the jelanis are 10 sand bars or piles of conal mubole. The Iargest, Loggerieac Key (ca. 30 acres), has a smail Coast Guard Iightiouse and staticn ana a gooc stand of lange trees, mainly Casurine. Garien Key is connated by Fort Jefferson, a forner arry cutpost and later a prison. Surting with a Netionel Audiocn Wociety whoren stationed on the inyeuges cuming tho igoj hesting sasin, tine

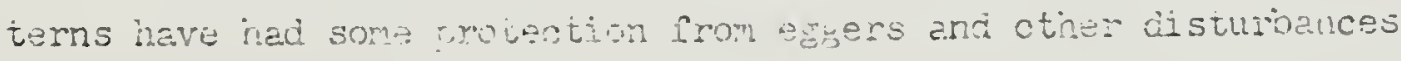




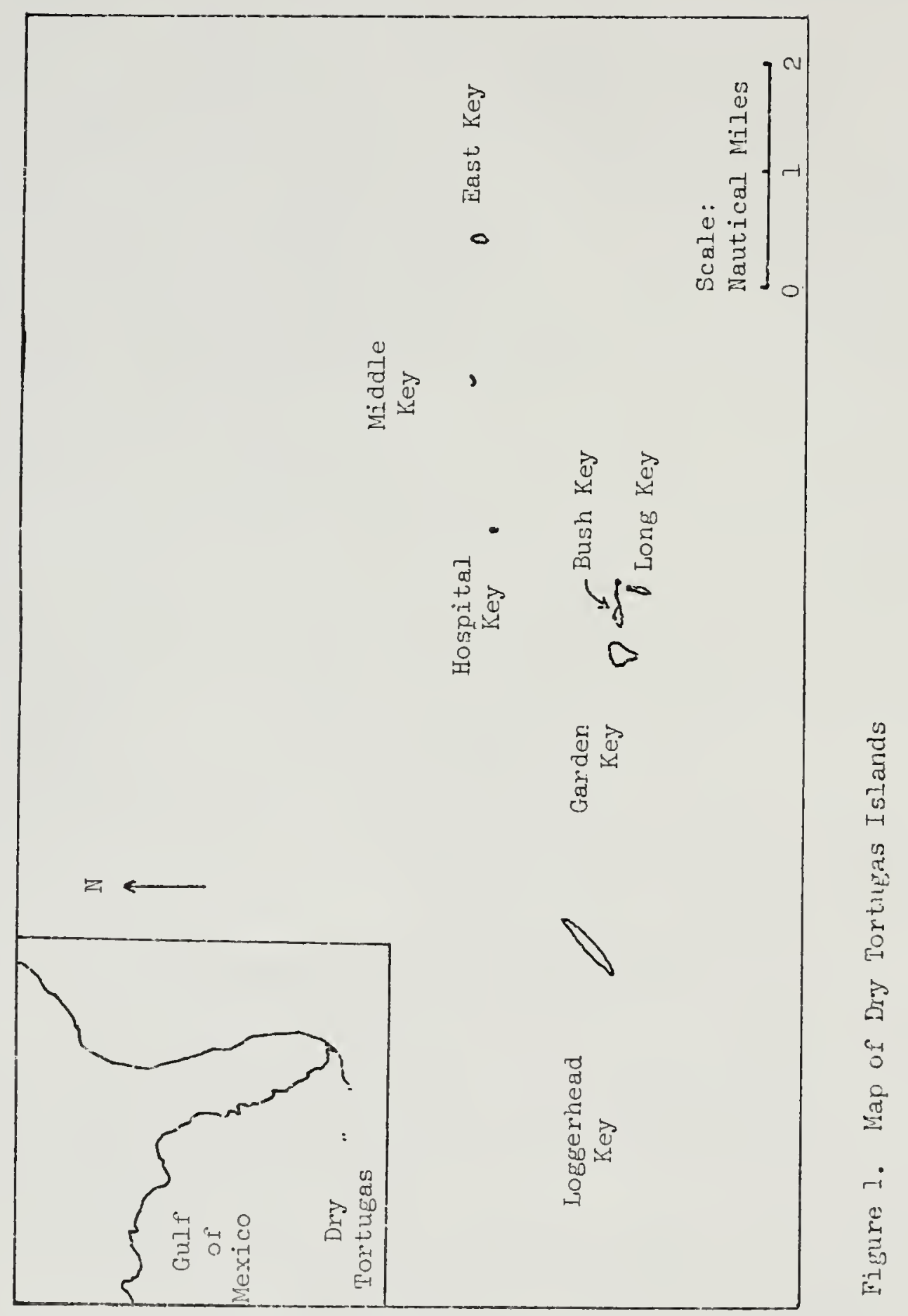


most subsequent years. Fort Jefferson was designated a Viational Monument in 1535, and its small pemanent human population provides some protection for tine terns in the nesting season. Hiddle and Hospital heys are presently just small bare sand bars. Fast Kej has some low bezch strana vegetation. Iong Key is a bar of rough coral rubble with a sma?l stand of mangroves.

I studied Sooyy Terns on Bush Fey, aurrently about 20 acres in extent and separated from Garden Key by e 500-5oot chaniel. It is composed primarily of coarse light-colored sand with coral rubile on the east end where a long narror spit joins it to Long rey at low tide. Maximun elevation is about 4 feet above rean high ticie, Bush Key apparenty was present in the mid-1800's, disappeared, and reappoared in the early 1900 s (Ruberison, 196́4). In this century it probabiy first appeared as a series of sand bars that eventually connecied. gained some vezetation, anc grarlually gren and stabilized.

Three mall orackish ponds in the center of the island are rirued

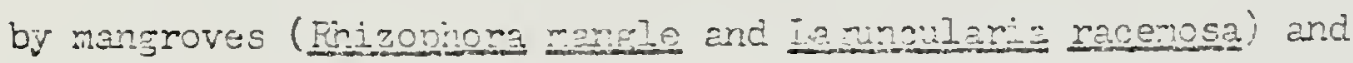
buttonwood (Conncempes erontrsi). Around them a thichet of bay ceciar (Suriane Maxitia' 6 to 6 feet tall covers much of the island. Cutside the bay cedar tincket and extending from it to the tide line, the vegetation is relatively lon and open. Viost Sooty Tems nest ou these flats, aithough some nest in openines in and under the mangroves or the bay cedar. The major piants on the periphery of Bush Key are sez

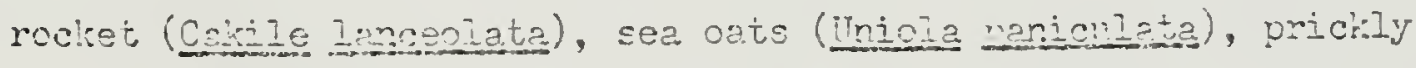

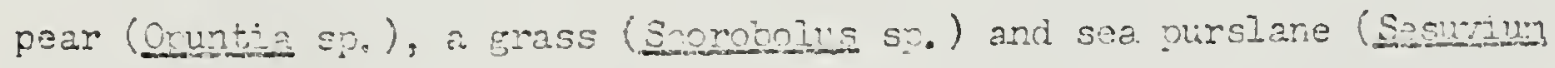

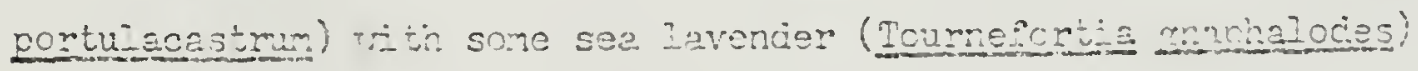
around the edees. The density of these plants varies fron year to 
year, primarify depending on the arount of rainfall..

\section{Fauna}

Besides Soty Tems, at least three other species of tems have nested on the Dom Tortugas in recent times. Wost nurearous today are the severai thousard 3rom lodiles that build a sinvle platerm nest of sticks anciead vesetation. in the bay cedar and other low vegetaticn on Bush Rey. The Black Nodit (Anous tenuirstris) has oser reported on the Dry Tortugas alnost yeariy since I959 (Fojertson, 1964) but as vet. has not been found nesting.

Least Tems (Stoma a Difrons) former. Iy nested on Bush, Long, and Loggerhead Keys but have not done sc since abotit 1950, while serere? hundred Roseate Ferns (S. dougizij) still nest yearly on the Dr. Tortugas (Robertson, iqót). Royal Terns (Thaiasseus raximus) and Sandrich Terns (․ Sandvicensis) rested on the Dry Tortugas in the I800's, but otier than a. single maximus egg found in 1952, no rectav nesing records exist (Zobertson, I9ói).

Of sone 2 Lo species of birds reported fron the Dar Tortugas, the only others kncun to have bred there are sone suocies of booby (S.le)

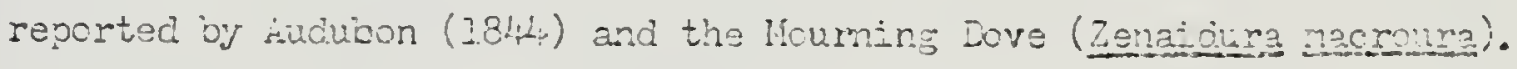

The only mamals reported from the islands are the introcuced rat (Rottus rattus) that at times has killed young bincs and destroyed ezgs (fussell, I938) and the West Indian SeaI (Ionachus trooicelis), currentiy faced with extinction.

Several land reptiles have been collected on the islands (Dieilman and Schmartz, 19,53) but apperertig rono has permanenily culonited the Eslands and they pose no trreat to the terns. his the nar:o of the islands surgests, sea turties fomerly nested there in great numbers. 
A few, probably Loscreriead Turtles (Caretta caretta), still lay their eggs on the Tortugas and occestonaly destroy tem nests when ther dis tines crm nests.

\section{Clinate}

The climate at the Dry Tortugas is best described as hot and dir. Daily terperatures often reach the low $90 \mathrm{~s}(0 \mathrm{~F})$ and seloum arop below the low bôs at right (Vaughan, igis). Tre intense radiation of heat from both water and the lightwolored sand creates a severe microciinate in the layer of air just above the ground, the microhabitat in which Scoty Terns rest. Rainfali probably averages loss than 40 inches per jear, much of it coming in sudden squalls. Severai hurricenes have struck the Tortugas in recent years. On 8 June 1966 the 123 moh winds of Furpicara Alna drove water over Bush fey and buried nany young tems in the sand. Hany died, but overall mortality was surprisinfly low (Wason and Steffee, 1966). On 3 june 1963 the center of Furricane ibby passed about 60 riles rest of the islande and heavy winds, rain, and waves belted the islands for sevaral days. The high waves vached array some egss lazd on higher parts of the beaches but did not stang rush Key, and mortality was very low. Adults with eggs or chicks sat tight on the scrape trroughout the storm, and some eggs hatched during the storm without noticeable detriment.

\section{Previous Work}

The earliest scientific studies of Sooty Terns on the Dry Tortugas are those by Watson (1908), Lashley (1915), and Watson and Iashigy (1915). They investigated its breeding behavior and made some proininary tosts of its horing ability. From 1.36 to 1941 some 
13,300 tems, mainly juveniles, vere banded at the Diy Tortugas. During the 1940's and 1950's lational Paxk Service persomiel and others visited the colon almost yearly and made estinates of its size in most years. Sumaries of much of this work appear in Spmunt (1948) and Robertison (1964).

In 1959 the National Dark Service, the Florida State Nuseum, and the Florida Aludubon Society began a cocperative banding urogram on the IrJ Tortugas tems. Robertson (I9ćti) surmarizes the histom of the terns on the Dry Tortugas and Iater (1969) docunents the transatlantic migration by juveniles from this colony. In the 12 years of banding scre 153,700 jurenile and 81,100 adult Sooty Tems have been banded on Bush Key. 


\section{METHODS}

I Iived on Garden Key from 29 Yerch to 10 ung 1968 and worked. almost daily on nearoy Bush Ker. I trected a blind near a smail plot $(25 \times 30$ jeet) form which I cleared nearly all vegetetion. Terns were captured in mist nets and 182 wero colormarked, each with a unique patterm of three colored leg bands and a Fish and tilicilie Semice ( $\vec{F}$ S) band for individus recognition. The terns gradualy acclimated to wy presence in the bind, and their behavior avpeared normal unce I was out of sight.

I cietermined the ser of the tems by noting their position in copulation, keering in mind that malewale mountings nay occur. Once the bircis weres coicminared, I recoried their activities and the roles of rales ard fentales in the cere of their eggs and chicks. As Sooty Terms spend much of their time flring, I had to limit ny studies to their activities at 5ush Key and its imediate, vicinity. After the eggs hatched, I tewhered sume chichs to vrevent thon from hiding throughout the aay. This altered their behavior, bui it tas the oniy way I could keep more than a few chicks $i_{i}$ sight after they were about 3 reeks old.

In 1969 and 1970 I spent shorter periocis on the islend after the joung hatohed. 


\section{BREADT:G ACTIVIRIES}

The yearly activities of Sooty Teris at the Dry Tortugas can be surlarized as follors: Starting in late January or Pebmary, Soowy Tems appear near the islands in numbers at night cnly, circilisg, caling, and sometimes landing, but generaily are absent during the day (Robertson, 1954). Graduzliy the teme start arriving at the 'Tortugas earlier each evening and also in freator numoers. Finally in late ifarch or Apriz they renain in daylight and land, diznIzy, copulate, dig a sorave, and lay a single egg trat is incubated 20 to 30 dars. The cilicis are closely attonded for the first reek or two and then are alons much of the time except when fed. Chiche Pirst. iny when about 9 weelss old and apparentiy Ieave Bush Key scon ajterrard. Scme juveniles are fliring by iate june and rost tejne nave left tre Tortugas by late sugust or eariy Septerber.

Little is knom or the activities of Scoty Teras avau fron tre colony. Out of́ sors 153,700 chichs bended on Eusin Yey, about Bo have been recovered atav from the colory and provicie sore informetion cu the morement of juvenizes. After leaving Bus! KeJ, juveniles cinipt west in the Gulf of Vexico and then suth along the eastem coast of: Centrai America, fizraliy moving eact along northerm South America ana out across the Atlantic in the vicinity of the equator. They spend

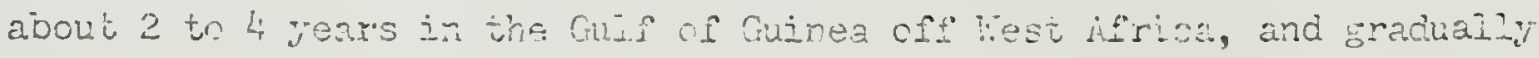

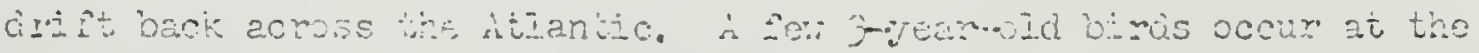

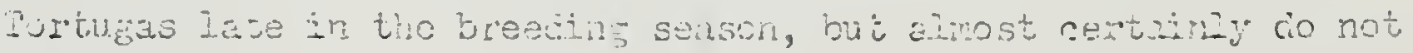


sometimes repeatediy, Flying low and often in pairs. They llew slcwly with deep wing beats. Their ilight resembled the low (fish) flight display described for other terms (Fainer, 194; ; Cullen, 29ópa), except that they jid not carry a fish in their bill.

In early evening, between 16:30 and 17:00, flocking begar. The tems approached the Dry Tortugas Irom the northwest, much as Robertson (I964) describes and gathered northwest of Bush Key, cirolins and calling. As more birds joined the flocks, their calls grew louder and the circling nore pronounced. Usualiy thay started in a loose flock of 50 to 200 birds circling 50 to 100 feet above the vaiter. They flew with a slow, seemingly exaggerated wing beat, often gliding betreen beats and drifting along in a circle 100 to 200 feet across. Eventually a few dropped low over the water and, assuming a nore ravid wing beat, made a fast circuit oyer the ejce of Buch rey and retumed to the Ilock over the vater. Gradually rore circied over tre island. A fow started landing on the oven sand beach on the north side of Bush Key. The calling got stili Iouder. Cccastonally all the biras on the beach flen rapidy and noisily back to the flock. There they circled and again started moving back toward the isiand. Around 18:30 the nurber of bircs gathered on the beach increased. Fewer flew when disturoed, and they returned sooner when disturbed. All this tire nore birds continued to join the circling flocis.

at over the water the flocking pattem changed slowly. At first all the tems were in one staging or circling flock, from which they flew to the island. As more birds arrived near Bush Key, more staging flochs formeri in a Iine stming out to the nortinest. Presumably birde entered the farthest one first and then noved from riek to flock as 
they apnroached the island.

On 5 Apri I at I.7:30 I could see three such flocis, one about 1,000 feet north of Eush Key and the other tro beyond. Eetween the Flocks I could see lires of birds flying with slor, exaggerated wing beats about 50 reet ahove the vater. Beyond the last staging flock a Iine of terrs, again about 50 feet above the nater, was stretched out for several miles. Eeming some biris aporoan Bush Key Jow over the water as they normally do later in the season, but nost drifted in with the llocks described above. The largest flocks I saw were north of Bush Keyr; occasiorially smaller flocis formed south of Garden Key.

After sundown more terns zanded and gathered in groups. on 10 April, a night with a fuil moon, most scoties were sitting quietly along the beches of Bush Key at $21: 30$, although a few still circled and ealled from the air.

At sumise no staging flocks were present, al though many biris circled and called over Bush Key or steved on the ground. 3y 08:00 most biras had left the island, flying to the northwest. The exodus was not so velz detined as the aporcach.

Flocking by Sooties is apparentiy a significant social activity. Perhaps its function is to delay breeoing by early arrivals at the colony until some critical nuber of terns is present. With adilt Sooties epparently spread throughout the Gulf of Vexico in the nonbreeding season, such flocking might synchronize the reproductive cycles of individual birds and insure that most sooties breed at about the same (most favoraile?) tine each year. 
gradual extensions of time spent on tree fround by night groups. Wo massive influx of tems with almost immediate egsmlaying was obsemred, although tinat, has been implied for this colonv (Thompon, 1903; Sprunt, 1945). Similarig on Ascension Island, arter a period during which Sooties are present only at night, they suddeniy start to retum earlier in the evening and stay later in the rorning, ari esc-laying soon follows (Ashmoie, 7953 ).

When I arrived on the Dry Tortugas in Iate :iaroh,1963, the tems had aireacy started staying later in the day so thai some were present until around 08:00. On I April I found three Scoty eggs on the west end of Bush Key, the first ôt the 1968 season. Vithin a fev dars more were laid near thase three, and also severai hundred feet sast of them near my bind. Egg-Iaving then seened to spread out from these two loci anci by 21 Anril eges vere present pirtualiy triroughout Busin Key.

On the plot I watched from my blind, egg-laying sterted later (9 April) and peaked around 15 April. Hence I followed the beharior of these birds beiore they laid thei: eggs. At first they appeared nervous and were easily frightened. They hovered over open grouric, landed briefly, and then flew in a panic (see p.63) alrost imeciately. Gradually more biras landed and began to fill the avizlavie oper ground, only to Ily at the slightest disturbance and ther retum and. go through the vinole process again.

As soon as the birds landed and settled dom, at least two postures became common. One of thase is the paracie that will. be described later. In tile other the bjra mints its bill dom, sometines almost burying it in its breast, futhers. This posture is ccrmon in iarids. Harrison (1965) calls it, tre "stare-dom" and says it seems to 
"cut of 1 " or end a low intensity agonistic or conflict situation. Sooties often give a staremown almost immediately after landing and then preen their back and wings. An almost fevenish amount of displaying occurred during these eariy morning hours in the sew days from the time they first stayed on the islard watì the female laid hen egg.

Little displaying occurs in the night ciuos and most of the birds just rest (Ashmoie, 1963). I made only one night visit to Busin Key during this period, and I found that most tems vere resting on the beaches or in open parts of the island with a few in the air. One evening when eggs rere present, I remainsi in my blind until well after dark. Even then the biras were highy excitable, panicking whenever I made the slightest disturoance. To prevent undue disturoance of the colony, I s.voided nigit work aro have little inforration on the bird's nocturnal activities.

\section{Pre-jaring Activities}

All or the disolays and activities leading up to egg-iaving may occur within a fer days after the binds Iirst land in daylight: Because 1 vas rarking biras at this time, there rene few I could foliow through the entire benavioral sequence. I also found that birds were stili moving around within the colony, since many colormarked birds immediately leit ny plot upor release and never raturned. Hence the sequenas of events has been pjeced together frou the few pairs that I could follow throughout this period and also by noting when vartons activitios ware nost comon on my pint. 
Leries. Pising

Early in the nesting seasun ard to a lesser sritert lazew, aerial displars are a charecteristic aotivity of Scotiv Terns. Cuilen (1960a)

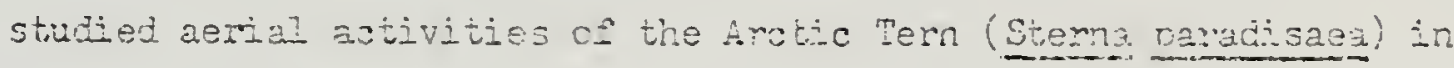
detai? and sumemaed much of the information avainuie 0.3 other tems.

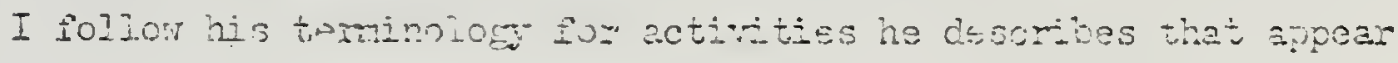
homologavis to those of the Sooty Tem.

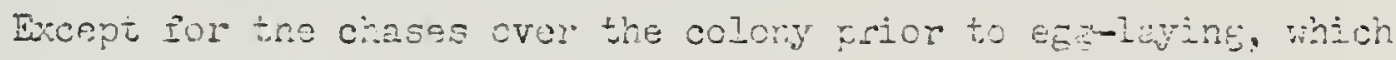

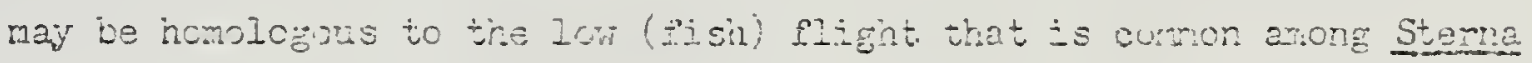
terns, aerial dispizy bir suties seens to consist sole-y of a high flight sirilan to that of the Arotic Tem (Cillen, Igcia).

In Soties, the nign singtis a slow steajy ascent by tivo or sonetins three terns to a height of sereral hurired feet and tiren a rapid gijding descent. I noted tro means of ascert. ore oftun occiuring after the other. In one the tro otrods ascender alnost veritically in small circles, İlaping their wings rapidy as tine lowen oird cheseci and occasionaly tried to gratp the tail of the upper birc. Inis seers comparable to tho uward Piutter, a hostile beisvio: that CuIIen (I060a) cescribes. I saw the upvard Ilutter at the start of only about 30 per sext, of ail aerial displays, but usuzl.ly it vias griven only briefly

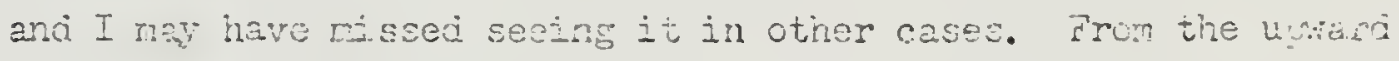
flutter, the biris chenged to sceningij exagzerated deso wing bents

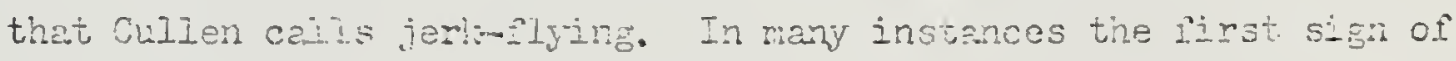
aeitaj. cisplay res this type of pight, and it ras tine initial fattera

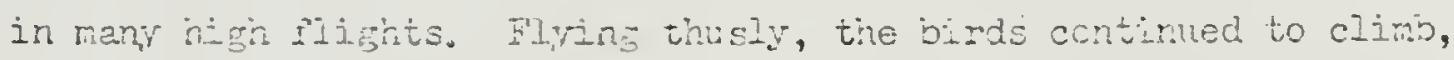

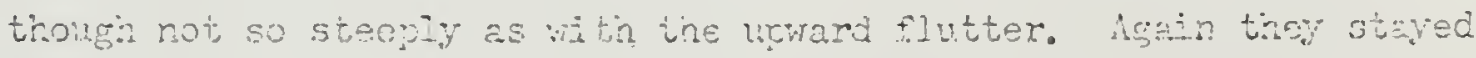
close tugotner as il one var chasing the other. In thase cheses the 
Iead bird gave = ratting "ka ka ka" call white the rursuer gave uptard-in looping circles above the colony and adjacent watsr, orten reaching a height of several hundwed reet. Trey soretires continued to ciinb for 2 or 3 rinuzes, although more comoniy they cinibed for abcut a minute.

At the pear of the flight, they osten crased briejiy and then maneuvered close to each other by ilapping thein iting in.sior, alrost half beats inth the rings barely moving to belon the level of the body. Then they began a rapid gliding dive. The angie ol' descent was usuelly fairly shallon at first and became steeper as they descenaec. Several times I noted that the pursuen passed the ieacing bird and took the lead at the start of the giide, and this maj be usual, much as Cullen (1960z) reports. In the dive one bixd vas above and just behind the other, the two about a foot apart. Both held their wings rigid; the Iover bird's wings were usually bent sliontly at the carpals and the upper one's w'ngs were held aimost straight out irom the body. Trey held the Iong outen rectrices "scissoi"ed" togetrer and in those instances where I could ses their bills, they pointed straight Iorwar. In this rosition thegr dove together, their moverents coordinated so that the secord bird closely followed the sometiries snifting end dodring fricht of the first. Sometines they started the blide sevwrel tiries, leveled cop after descending a short way, and then ciove again. At other times trey surpated and each flew away àone. In a comolete display they gitded togetren covu to just above water level, swoped up a short weys und tiren separated, each Mly-ing anay in a normal flight. Severai times I followed both biras afier the Eilde, but I 
never sa. them stay together to reveat the nigh flight.

I sav rumerous variations of the ingig flight. Of 50 high flights in which II saw all of tine display, I. started with the upward flutter and 32 with jerk-inying. Thirteen times the birds changed from the upward flutier to jork-ilying. Thus jerk-flying was part of the ascent in 45 of the 50 high ilights. The other 5 times the entire ascent was with uvward IIutter. In 40 high fligints the two oirds circied after this ascent, mainly by jerk-plying. The birds started a descending glide in 47 of the 50 high fiights out continued to glide down to about sea. jevel in only 28. Thus ascending by jeri-flying and descending in a glide are the two most conspicuous parts of the high flight, altinough they do not occur in all of them.

The birds often change positions, ijost one leading and then the other. These changes occurred both during the ascent and in the glide. In the Elide the charge was maje oy the upper oird moving beneatin the Iower one. I was not able to deternine the sex of the birds ciuring the aerial dispiay.

Except tinat Arctic Terns sometimes carry a fisi in the higi filigit (Cullen, 1900a), the hish fiight of Sooties seens very similar to that descriosd by Cuilen for the uretic Tern.

Aorial dispiars vare nost comon from 15:00 to 19:00, but I aiso saw sone in eanty moning. Host ccourred eariy in the breecing season in Apriz but I also say scise in ivy, June, and July when they may have been given by Iate arriving aduits or renesters. inforturtely I did not see the events on the ground that preceded the ing filignt. The iurction of the high Iligint is not knom, but Culien (1900a) suggescs that it may be part of nain torration. If* so, perinaps the 
high flights lace in the nesting season involve young birds. As Sooties as young as 3 years old visit Bush Key late in the nesting season but projobly do not breed for several years, pernaps they pair a year on more earlier. It is not know how long Sooty Tem pair bonds last but it rould rot sumpise me if the same birds pair in successive years. Such an extended "engagement" period is known for enotiner long-lived pelagic species, the Larsan Albatross (Diomedoa immutabilis) (Fisher and Fisher, 1969). Moynihan (1962) also sam many aerial disclays by Brom Nodaies and the Inca Tern (Larostema inca) late in the nesting season, and suggests that at least in the Inca Tem these may have been young birds pairing. Brom loddies at Bush Key also ccrmonly give asrial displays late in the nesting saason.

Ground Activities

Farade.--Onee the birds landed and stopped the alrost continuous panicking, dispiays on the ground began. The most constcuous ground display of Sooty Terns is the parade in which it assumes a distinct posture and dispiays to other birds by prancing rapidiy with short, qui.ck steps. A bird may prance toward, in front of, or around arother tern; or tro mey prance together, moving paralleI to each other. Palmer (1941) describes a similar display in the Common Term (stepra himudo) and says it tares tro different foms, each with a difierent motivation. Aithough $I$ isar these tro forms in sooties, I sax much variation in posture betwen the tiro extremes.

In the parado posun:ea a Soty extends its head and neck far forward, often sieking the featiers. The wings are usually held well away from the bow, raticularly at the carpals, and are sometines lowered until thsy draz on the ground (Ficure 2). Occasionaily the 


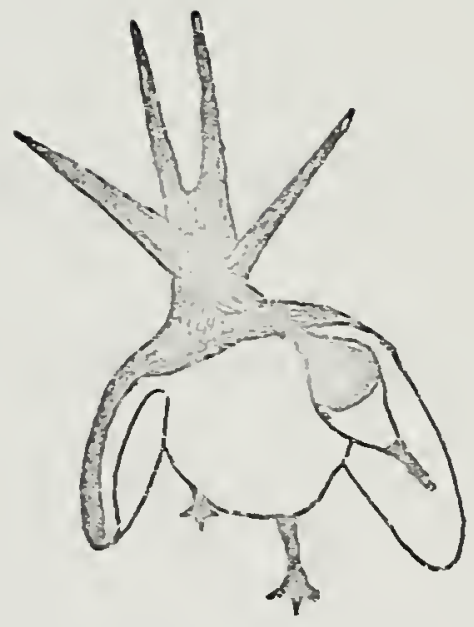

Figure 2. Fosture oi Sooty Tern in the parade display (taien. from irtiale, 7914 ). 
wings are heid tight aganst the biri's sides. Usually the tail is tilted uprard and often the tips oi the prinaries cross unier the base of the taii.

If the oizi is pointec uprard, it is called the erezt posture and Palmer (1941) sars the dispiay shows subnission. Scoties may point the bill horizontaliy o" slightly ebove rorizontal but selciom point it straight up as some other terns do. Sosties also tilt their head to the side, espevially when displaying witr oy to another oird. Then they tip theis hesd arey iron the other individuel bus sem to lean the body even more torewd it so that the near wing of ten dires on the ground.

I sar Sooties give this disclay almost imediateiy âter landing on the ground. Often it preceded copulation but other times tro birds separated after parading. Both sixes gave the erect iorm of the naraie, wut rhen one bird circled and obvousy displayed to anotiner, whenever I could deternine the sexes, it was alvays the male that did so. As the eract form of the parade vas connu aimost

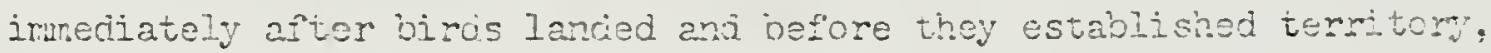
it certainly is incontant in gair sormation.

In the other fom of the paraie, the tern points the bili dom, but sooties seldom point it arectil at the ground. Paimer (194I) calls this the bent position ard says it is given when a tern tries to intimidate arother term. Sooties do not taice so extreme a posture here, usilally not noluing tho wings so far away from the boay or stretching the neck so sar for:: with the oill pointing liprarc and end with its panting toramo the ground. Tims the position of the bill varies considerably. 2ltrough 
the bisic ving and dody postures are sinilar in the bent and erect forns of the parade.

Both Palmer (1941) and Cullan (1060a) note these tro bill positions occurring in aeriai displays of terns. Although I ratched for this, in all cases that I could see the bill was pointed straight forrard, the eerial position apuarentiy conarable to the erect on the ground. In the bigh flight Sooties usualiy ily abay from tise island, so I may just have been unable to see the cirds re?l enough.

The only calls I heard associated directly with the parade rere occasional 10:" "whk sul" rotes, out ustaliy the biras were silent. Once I noted tine throat of a paracing male vibrating ravidly, but aithough I was only 10 feet aray I heard no sound. Notes too lotv for me to hear may accomany the display.

Several times I sain a bird on the pround raise its head and gire a loud "ke-wat-ic" or "wen-dick" call that was ansirered by a secore bird in the air. After the tro exchanged several calls, the seconi bird landed and then the trio paraded. In one exchange the male calied to the fomale, and after parading the tro copulated. Apparently the male called to attract a Iemale and ther paraded to ner. fis the erect form of tine parade was most conmon when the birds first landed, I think it functions aions with the high flight in pair formation. Courtsing feacing.--I sav courcsho feeding only in times, mainly from 13 to 20 April Dut once as İte as 17 June. Hot alI of these teminated with the actual transier of food. Mere the sex was known, the female alirays bogged. Cenerally sne crouched, turned her head torere tise male, anc gave a rapid series of lcii chuckling "la ka" or "yip yip" notes, raising her oyon bill torard hin, and biting at 
his bill, much as a young tem begs for food. A feri times I actualiy saw the male transfer food to the female, sometines repeatediy in one bout of courtship leedins.

Decasionally the parade preceded courtship feeding, but the latter is relatively rare and certainiy not a regular comoneni of the parade. Courtship feeding is a typical precopulatory behavior in most Larids (Cullen and Asimole, 1963). In Sooty Tems courtship peeding seered to be relatively rare and only occasionally preceded copulation.

Copulation. - The parace commonly precedes rounting anc copulation. The male parades in front of and around the remale, stops beside her, and then mounts. The female crouches, holds her wings out from her sides, raises her tail, and stretches her head forwara. The male then moves back on the female, crouches, and copulates. After coitus the male dismounts, and tine two usually fluti thair body featiers aid then preen. A single pair may copulate repeatedily.

Copulation was cormonest on my plot from 6 to 23 April. 0 i 208 times I noted a male trying to mounc a female, in only 56 (26. 9 per cert) did they seem to copulate. In 68 (32.7 per cent) attempts the male fell off the feraie, the female did not crouch, or he simoiy dismounted without tring to copulate. Mole commonly ( 84 times, 40.4 per cent), another bird interfered and either knocked the nale ofi the female or the male disnounted and fought with the intruater. Interierence from other biris became comnoner as the breeding season progressed and eventuaily fow pairs could ecpulate without other birds interiering. Several tines I saw two to six males try to mount one female. 


\section{Establishing Ierrizories}

Sooty Tems acuarentiy do not establish temitories until after copulation. Iven then the terrjogy is not permanent until they finally aig a scrape and the fomale lays an egs. Nomaily sooties clain an area spannirg little more than what they can reach while sitting on thein egg. The scrape itself is a shallow hollon some 3 to 4 jnches in diameter and about an inch deep.

Scraof-guilding.--By 10 ApriI scrape-building was conmon ca my plot and from then until le kprit it was the bird's most conspicuous activity. Although scrape-buildiing obviously provides a site for the egs, the incipient scrave-builains behavior associated with it often occurs before copulation and seens to be part oz couriship in Sooties, much as it is in Comon Terns (Falmer, 1041).

Pairs of Sooties usualiy suend some time selecting a site and may make several. faise starts. While selecting a site they walk together, poke at the ground, pick up bits of gravel, sheii, or vegetation and then drop them; start rork at one site only to abardon it shortly, and continuously give low "puck puck" calls. Typically two birds stand close together, point their bilis toward the grourd, then lower their body, and kick dirt back with their feet. They often give low "puck puck" notes as they poke at the ground.

Wearly always a pair works together to diz the scrape. Usually the male does most of the digging but the ferlale helps at least occasicnaly. As they work at the scrare, they pick up srail peobles, shells, trigs, or other small objects and sometines drop them Into the scraps.

Scrape-building generally otops once the female lays her egg, but 
the birds occasionally work on the serape after it contains an egs. Several pairs that lost their chick shortly after it hatched vegan work on new sorapes, but I did not see any bird lay again, Fighting.-Conspicuous fighting started around 11 ingil whon scrapes were being cug. In fighting, two birds face eich othor, sometines approaching each other wth their heads and bocies held Iow and forward or else upright, the head erect and the crom feathers raised. The two hold their wings out from the body and usually hold the tail up. Usually each jabs viciously at the head and biil of the other bird on glips the other bird's bill and then coth shalve their heads vigorousli. Cecasionally they beat their opponent with a wing, but nomally the wings are used only for oalance. Sometimes they give Icw rasping growls. Finally the two reisease each other and each retreats to its cun scrape.

While some foighe ended with one bird cleariy supplanting the otrer, I often saw ther end differently. The two birds stopped scuftling, faced sach othen thth wings against the body, oills fomarc; and First. one ano then the other lowered its vill into the bent posture and turned its head slowiy ary and then broks ofi the altereation. Occasionally thoy gaved at eack other bafore Iowering the bill. Gaping apparenty is an aggressive signal (Moynihan, 1962) as is the bent position. Thus the ageressive display apparently ended the fight.

The starv-iown posture described earlier also occure commony after fignis, After a peired bird drove off an intxuder, it comonly guve the stare-avin upon returing to its mate. Again the aggressiveness seemeri to end with the staremdom and tre bird tumed its atterticn back to zts mate. 
Thrus the sequence oi everts praceding ergs-laying seems to be as follows: First the terns Flock and land on Bush rey every evening in a mass social activity, perhats synchronizing the breeding cycles. Gradually they extend the time they sperd on the ground and as flocking desreases, they begin individuai sexuai activity. Uaies seem to land, perhavs near where they bred in previous years (see p. 75 ) and call to try to attract fermies to them. When a female lands, the parade and high ilight that follow probably contribute to pair iomation. They continue courting with parading and incipient sciapebuilding until they copulate. The two then dig a scrape and oegin to ciefend tive area immediately arounc it.

\section{Incubation veriod}

\section{Es:-12ying}

After copulating and then working on a scrare for several days, tre female Sootj Tem Iajs a single egg. 111 14 eggs whose time of laying I was able to detemine accurately rere laid in the afternoon; five betreen 12:00 and 14:00, five between 14:00 and $16: 00$, and iour from 16:00 to 18:00. Rídiev and ercy (1958) and Ashole (1963) aiso note that Sooty Teris usualiy lay their egs in the afternoor. Hfter the first eges were laid on 1 ipril 1968, egs-iaying

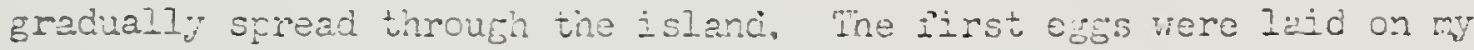
plot on 9 foriz and the peal: of lajing there was 15 fipril.

lisually doth rerbers of a pair are prosent when the egc is Iaid. lre iemaie cruches iot in the scrace winile the raite stands nsaroy, occasionally walkn around har or poing at the ground. In the first

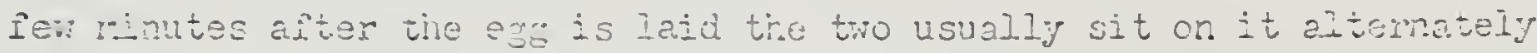
several times. The tomale lonies the ess, ialks around it: and the 
male takes over. He pokes at the egg, rolis It into the scrape if it was laid on the ecje, and in general worries over it before firally sectling down to shade or incuote it. Usually the fenale filies witnin about 10 minutes, apparenty to drink and dip as she often returas with her breast feathers wet. The two then stay near the oseg, İrst ore and then the other shading or incubeting it. Ixchanges row, as later in incubation, consist of one bind forcing the other oif ting egg and then taking over care of it. Exchanges are frequent during the first few hours after the egg is laid, but by eariy the following morning the male assures care of the ege and the femaie is absent. presumably feeding.

During inzubation and to sore extent after hatching, besides noting wich adult cared for the egg and the adult's generai cehavior, I maintained accurate records of activity patterns oi 15 pajes in the following manner. I made a complete catalog of the bird's activities, described below. I knew the date of laying and I could aistinguish the sexes of each of these pairs. In the activity records, every 30 seconds I made a I-second "spot" observation anc record of the bird caring for the egg, assigning the bird's activity to one of several readily idistifiable categories (e.g., incubating, shading the egg, off tine egg and preening, etc.). This method of naking 120 ojsemations per nour per nest was used for I-nour veriods throughout incubation. One fault or this method is that by cataloging activities, slightly different activities mist be grouped in a singlo category. The categcries with the most variety are those that occur when the aduIt is off the egg, and as the aduits either incubate or shade tine egg more than 90 per cent of the time, this variation is only a small 
fraction of ail the birk' activities. The other alternative is to watch a few nesis continuously and record all the activities. Even in a Sooty Tem colcny, where nests are close togetiner, it is dificult to follow all activities at a for nests, escecially when several suddeniy erupt into activity with fights or other interastions. Watching a fer nosts involves the risk that some or ail of them may be destroyec, descrted, or otherise disturiod.

On the practical side, continuous watching of a few nests is very tiring. By viering 15 nests, I kept my eyes noving anci trus avoided some of the monotony and fatigue of contiruous watehing.

I analyzed these activity records by sex, hour of day, and date in the incubation cycle, excluding all l-hour watches in which exchanges occurred. During incubation, I have reconds for 1,632 bird-hours, each including 120 spot observations for a total of 195, 840 snot observations. These incluce at least one hour o watchirg for each sex for each of the 12 daylight hours for most days during incubation, and for some I have many more. These were used to prepare Figure 3 and Table 1.

Behavior Drring Incubation

During incubation Sooty Iems primarily tend the egg and periom a few maintenance activitites during brief spells away fron it. I categorised their activities into the following types.

Incubation, in which the adult bird places one of its tro brocd patches directiy against the $6 g$, is obviously one of the most important activities, Sooties incubate mainiy at night, in the cariy moming, and in lato afternoon (Fiegure 3).

As the air tenperature increases in the morning, aidults gradually 
Figure 3. Activities by adult Scoty Terns during incubation. 


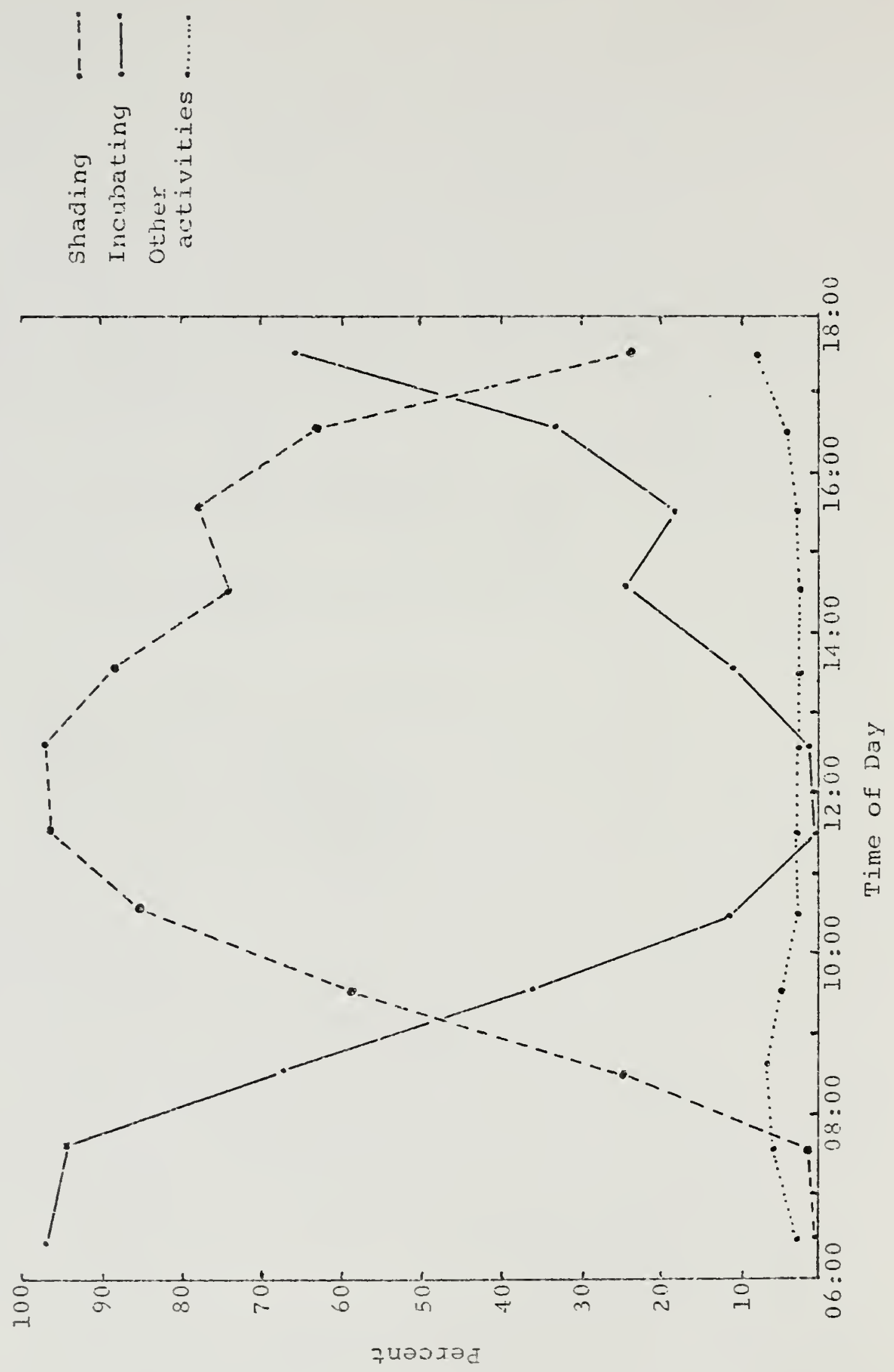


rise up off the egg so that most days by around 10:00 they are shading the egg rather than incubating it. They usually continue to shade the egg uritil around $17: 00$, when they gradually change back to incubating again (Figure 3). To shade the $e g g$ the adult merely stands over it and keeps it in its shaciow, As the sun changes position during the day the birds turn to keep their backs toward the sun. This keeps tine maxirum surface area of the body exposed to the sun and, as the upper surface of: a Sooty Tern is black, would sem to present problers of heat load for the bird. However, keeping their back toward the sun best insures shading of the egg. By tuming one side of its body toward the sun, the adult could probabiy lower its heat load, but it also would be nore likely to expose the egg to the sin. The aduits probabiy reduce the heat load several. other ways. As it becoms hotter, they erect their backfeathers and hold their wings out from their sides, increasing insulation and the area for heat lcss. They also gape widely and pant, apparenty dissipating nore heat than in nomal breathing. Another corruon activity is dipping as described below.

The change Prorn incubating to shading and back again is very gradual and proved my most difficult choice in recording activity. Figure 3 shows clearly when this change is made. Both jncubating and shading juvolve direct care of the egg. All other activities, in which the adult is not actually caring for the egg, are shown as the bottom line in rigure 3.

Among these other activities, the most freouent is standing to the side of the egg and preening (Tabie 1). Incubating adults comonly rise up off the egg, poke at it, and apparently turn jt. Other times the adult walks around the scrape or to the edge of its tarritory 
Tabie 1. Activties other than incubating ou shading by Sooty Terns caring ior an $6 \mathrm{~g} b$

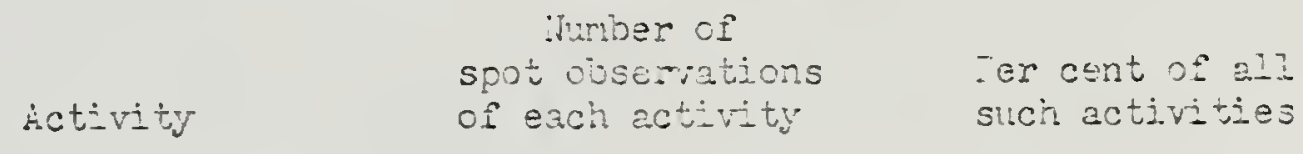

\begin{tabular}{|c|c|c|}
\hline Preening & 4258 & 48.4 \\
\hline Poking at egg & .2540 & 17.5 \\
\hline Standing beside egä & 1171 & 23.3 \\
\hline ivajeng & 886 & 20.1 \\
\hline Fisgiting & 673 & 7.5 \\
\hline Oif and from scraye & 276 & \\
\hline TotaI & $88 \mathrm{CH}_{4}$ & 200.0 \\
\hline
\end{tabular}


and siands. Jecasionaily a bird leaves its egg to spar briefly with another tern, either a neighbor or one that has come too close. Generally Sooty Tems are much less bellicose during ificubation than they are earlier in the nesting cycle or aiter eggs hatch. Perhays home ground is permanently established and recognized, and the absence of chicks to jntrude on others' territories enhances stability.

fidult Sooties cormonly defecate near their egs. They walk to the edge of their territory and turn to face the egg before defecaing. Sometimes a stretching rotion accompanies defecation. The bird stretches both wings vertically above the body, leans forward with head outstretched, and lets fily, thus stretching and defecating in almost the same motion.

Another activity of adults during incubation is suddenly flying away leaving the egs unattencied. On some occasions the birds fly away when panicked and return almost immediately. Other times this seems to be associated with the aerial activity called dipping.

Attentiveness

Sooty Terns are closely attentive during, incubation. The percentage of tims adults spend incubating or shading difrers only slightiy between sexes. Females spend a little more of their tirie incubating and males a little more shading, but with incubating and shading combined, the total attentiveness, anglyzed by hour, differs by less than 1.2 per cent betiveen sexes, In 211 , the bird caring for the egg sperds over 95 per cent of the davlight hours either incubating or singding and only about 4.5 per cunt in a variety of other activities (Table 1). These other activities prevail from 0?:00 to 10:00 and from 17:00 to 18:00, the times bhen inds shift 
betireen incubating and shading (Figure 3). Presumbly at these times eğ and air temperatures are much the same and care by the aduit is not so critical. Scoties are most attentive from iz:00 to 15:00 and scend over $98 \mathrm{per}$ cent of their time directly caring for the egro, mostly by shading. This is certainly the time when the egs experiences the highest envirormental temperatures, and presunaly when adult care is vital to the embryo's survival.

\section{Iriping}

An activity of Sooty Terns at. Bush Key that is especialiy noticeable during hot midiay hours, but occurs occasioneily throughout the day, entails their Ifying rapidy from the islard, briefly dipping their biII, leet, or breast featrors into the vater, and returning to the island. When only the bill is skimmed along the water's surface, it seens obrious that the birds are crinking, but aipping the brast feathers requires another explanation.

Usually each bird flies directly and rapidy from the colony at a height of about 10 feet. It then drons dom, dips the bill in the water, drags the feet in the rater, and sonetimes alrost lands monentarily, weting the feathers in the process. About 100 to 300 feet offshore the bird turns abmptly and files back to the island. An individual may dir fron one to as many as ten times on one flight. In 113 flights between 13 Way and 7 June in wich I recorded from a boat all dipping movenents, and also whether the birc Ianded back in the colony or with groups of terns suming on the beach, over 80 per cent of all dipping occurred on the flight out. In about 95 per cent of the flights the uinds dipped the bill at least orce (Table 2), and in only about if per cent thoy dipped their breast feathers. As one 


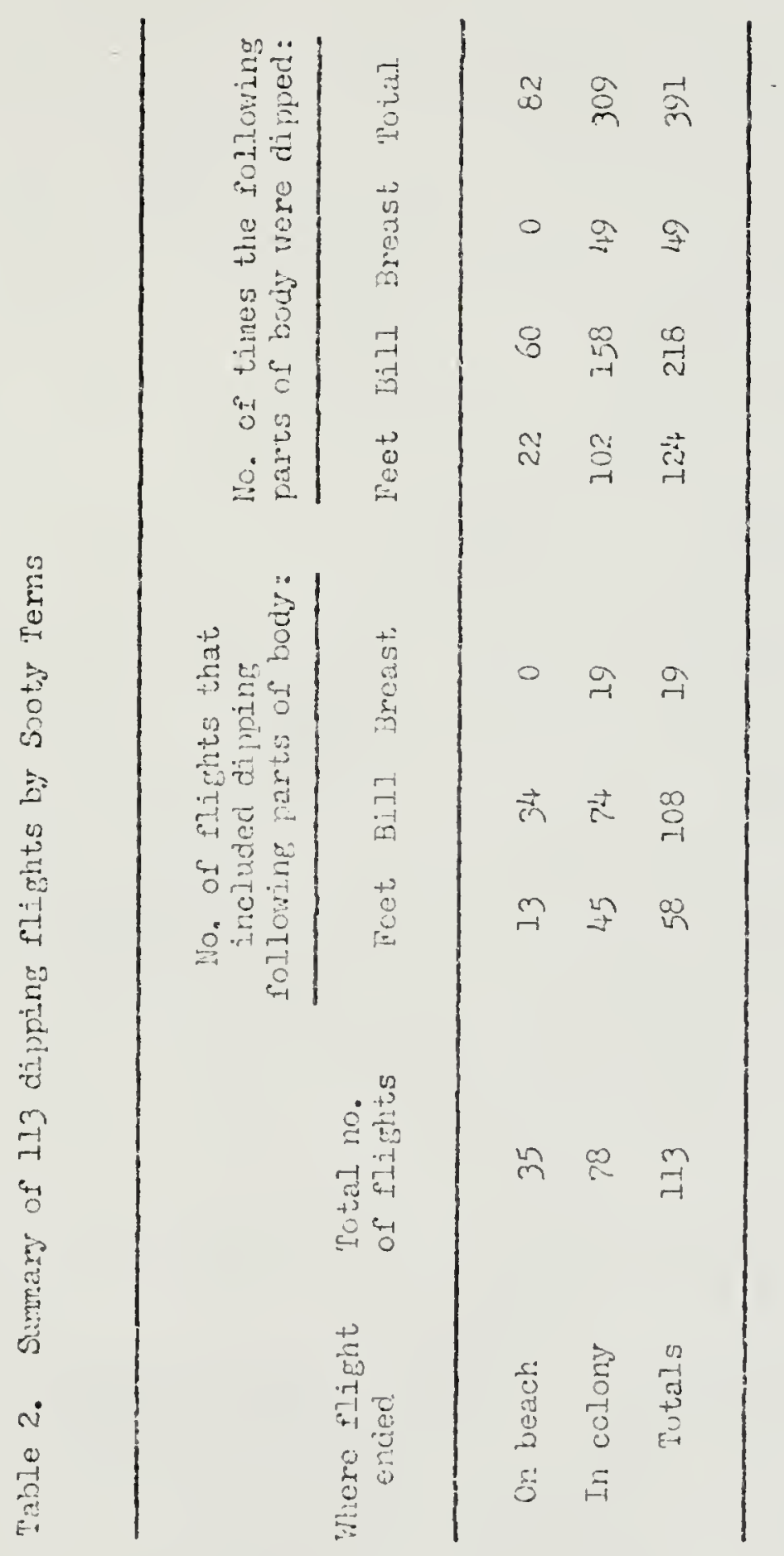


dipping moticn might result in more than one part of the body being dipped, I recorted the number of times each part of the body actually was dipped (Taoile 2). The number of tines a bird dropned down to dip is sorrewhat less.

None of the filghts that ended with the bird landing on the beach among birds suming or resting included dipping the breast feather's, while about 25 per cent of the flights that ended with the bird going into the colong where eggs and young vere present included dipping the breast feathers (Table 2). This suggests that dipping the breast feathers possibly has some relevance to nesting, sonetring also sliggested by behavior I noted at the scrape itself.

Often during the not nidday hours, I sar a single bird fly from its egg, not in a panic, and head toward the water (Table 3). After about a minute it returned, flying low and rapidly tcward the scrape. As the bird settied back on the egg, I often could see that ius bill, feet, and somatimes the brast feathers were wet. Obviousiy these direct flights from the egg are the start of the dipping ilignts that I watched ovew the water. As dipping is nost common when it is hottest, it seems possibie that this behavior is themoreguitatory, botin for the aiult anci the egg. Both sexes din with equal frequercy (139 to 137) so I have comolned their records. Diping by incubating adults is most frequent during ting first is days of incubation (Table 3). Watson (1908) rentions an activity similar to dipring but says the birds were bathing. The Ashnoles (1967: 62) note that incubating Sooties sometiries fly of to drink. Both Tonpkins (1942) and Hariy (1957) hare seen Least Tems dip thein breast feathers during incubation and susest that it provides water necessary for the eEss. 
Table 3. Tire of occurrence of flights airay from the ego by adult Scoty perns

Murber seen during:

Time First 15 divs Second 15 davs of incubation of incubation Total

$\begin{array}{lccc}06: 00-07: 00 & 4(4)^{3} & 1(1) & 5(5) \\ 07: 00-09: 00 & 6(3) & 0(0) & 6(3) \\ 08: 00-19: 00 & 8(7) & 5(4) & 13(11) \\ 09: 00-10: 00 & 31(24) & 4(3) & 35(27) \\ 10: 00-11: 00 & 31(25) & 11(8) & 42(33) \\ 11: 00-12: 00 & 24(18) & 5(5) & 29(23) \\ 12: 00-13: 00 & 21(19) & 17(15) & 38(34) \\ 13: 00-14: 00 & 24(20) & 14(11) & 33(31) \\ 14: 00-15: 00 & 23(20) & 4(4) & 27(24) \\ 15: 00-10: 00 & 18(12) & 3(3) & 21(15) \\ 16: 00-17: 00 & 20(14) & 1(1) & 21(15) \\ 17: 00-13: 00 & 0(0) & 1 .(1) & 1 .(1) \\ 10+515 & 210(166) & 66(56) & 276(223)\end{array}$

a. Tumoer of times in cotivity records birds were anay fron ege.

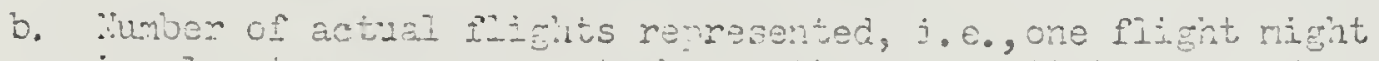
involye two or rore srot cbsemations ar actuvtr reconds. 


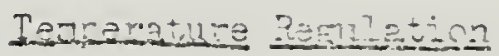

Howell and Parthoionew (1962), Working on Widwa Ialand in the Facific, show the delicate role that varental care plays in preventing Sooty Tem egrs From aprocaching the high and probably Iethal tenoeratures the would reach in open sunlight, un lidisy the acult maintained the eje temperatire above that of the surrounding air and below that of the surrounding sand. infortunately they do not say whether the aduts is incubating or shading the egg.

I attacned themisters to several eggs and monitored surface temperature of the egg and air tenoerature at about 4 inches above the ground for parts of several davs. Infortunateiy the egcs I worked with were close to m blind, and the acults caring for them were easiig disturbea by movenents. Also the wire attached to the ege hinderec the tern in turning it and affected the bird's beravior.

I obtained usefui information from a 24-dar-old chick on 8 iune and conflicting infomation from the same egg the next day. in 8 june, in 23 temperature readings taken between $10: 20$ and $13: 05$, the egs averaged $101.5^{\circ} \mathrm{F}$ (range 99 to $105^{\circ} \mathrm{F}$ ) and the air at 4 inches averaged 105.5 $\mathrm{F}$ (range 103 to $108.5^{2} \mathrm{~F}$ ). The highest egg temperatures occurred when the adult Iestit to dip or flew ofi in a panic. In ooth cases the adult dipped the breast feathers before retuming to the eqg. The next day in 35 readings the egg temperature averaged $105.20 \%$, somerhat above the air ter.perature that day (2050\%) and 3.70F atove the ezg's tencerature on the $8 \mathrm{th}$. Although the aduIt, reneatedly left the egg to dip. It seemed unable to lower the ege's temperature. is the egg cracked Inter that day and proved infertile, perhaps the keat of decay foiled the adult's attempts to lower the egg temperature. 
On the oth the acult had been able to maintain the egg's temperature some $4^{\circ} \mathrm{F}$ below the air tenperature. Winen the ariut flew off to dip, the excosed egg's surface temcerature rose I to 20 F while the bird was absent but then aropoed 2 to $5^{\circ} \mathrm{F}$ witnin a Eer minutes after the aduit, returied. The adult did not hold the vet breast feathers against the egs, but held them risgt absve the egg.

Although I have Iimited infomation, I suggest that dippirg the breast feather's by incubating terns helps pegulate tither tive egg's temperature or humidity. Some zdults dipeed often during incubation while others did so only rarely. If dipoing the breast featrers is themoregulatory, it is puzzling that the tern does not hold the wet, cool feathers directly against the egg. Fossibiy the water dripoing off the feathers onto the egg provides moisture needed by the ezs:

Late in the breeding seascn adults contirue to dip but selcon dip their breast featnexs. in 27 wne 1970 when most chicks riere 6 to 8 weeks old and few egrs were present. on Bush Key, nearly all of the hundreds of adults flying out dipped only their bill or occasicnally their feet.

\section{Nest PeIief}

Most of the 6I nest reliefs cbsemed during incuioation occurred during eariy moning or late aftemoon (Table 4). Cenerally the adult lanos near its scrape and walks up to its mate on the eg: on the egg either steps of f the egg so the secord bird can incubate, or else the nercomer pushes the incubating bird off the egg and tinen takes over care of it. ito elaborate ceremory ozcurs. The relieved bird generally flies aray within a few minutes, presumably to drink, but often returns to the scrave and Iingers for several hours on more 
Irole t. Tine of nest relief diring incubation

\begin{tabular}{|c|c|c|c|}
\hline Ti.re & $\begin{array}{l}\text { humber o: } \\
\text { exchanges }\end{array}$ & $\begin{array}{l}\text { Houns of } \\
\text { ciosemeticn }\end{array}$ & $\begin{array}{c}\text { Exchanges/hour } \\
\text { Obsemation }\end{array}$ \\
\hline $06: 00 \sim 7: 00$ & 13 & 21.52 & 0.00 \\
\hline $07: 00-08: 00$ & L & 27.92 & 0.14 \\
\hline $03: 00-09: 00$ & 4 & 29.03 & 0.13 \\
\hline $09: 00-10: 00$ & 3 & 23.50 & 0.12 \\
\hline $10: 00-11: 00$ & 5 & 19.33 & 0.25 \\
\hline $17: 00-12: 00$ & 1 & 13.35 & 0.07 \\
\hline $12: 0 C-13: C 0$ & 1 & 10.33 & 0.09 \\
\hline $13: C C-14: 00$ & 3 & 10.25 & 0.29 \\
\hline $14: 0 \hat{c}-15: 00$ & $I$ & $10.9 ?$ & 0.09 \\
\hline $15: 00--16: 00$ & 3 & 24.78 & 0.20 \\
\hline $16: 00-17: 00$ & 12 & 16.93 & 0.70 \\
\hline $17: 00-18: 00$ & 6 & 17.00 & 0.35 \\
\hline $18: c c-19: 00$ & 3 & 4.50 & 0.67 \\
\hline $19: 00-20: 10$ & 2 & 1.17 & 1.70 \\
\hline DoteI & 61 & 220.46 & 0.27 \\
\hline
\end{tabular}


before learung Eusi ñey. Sometimes this birc forces its way back onto the egg so several exchanges occur before the new bird finally takes over and the other leaves the island. I never saw an adult feed another ore at a nest exchange during incubation.

Although I sui some excuanges in midday (Table 4), riost birds retum to the colony in the evening and ralieve their mate then. Instead of circikng near Bush rey as they do earlier in the nesting cycle, returning aciults fly directly to the island and presumably to their scrape. Some circle over the island itself, calling loudy so that gracually the cclony becorles noisier. The number of hours I watched in early evening is ruch smaller than for other times. Otherwise I certainzy would have seen more exchanges then.

At Bush key fer adults resurgitate when mist-nettec in the morring or early afternoon, out many do so in the late afternoon, indicating they just returned from feeding. The exchanges I sar around sunrise mav have been pairs making a final exchange after several exchanges during the nigit, and the relieved bird was at last leaving to fecd. Wuch as when the colony is forming, the noise gradually diminishes and by about 08:00 few birds are in the air. Those that remain at the cclonv incubate quietly from about 08:00 to $16: 00$.

Asimole (1963) fourd nest relief most abundant from $21: 00$ to 06:00. He reasons that arriving at that time means that they fed durirg daylight and then ile: some $;$ to 8 hours to arrive at the colony in the middle of the night. I have no records of changeovers from $21: 00$ to 06:00, but the mass ve influx of tems early ir the evening sugsests that changeovers are comoner then than late at night as they are on 
Ascension Islard. If Ashmole's reasoning holds, then Bush Key Sooties feed within a Per hours flight of Bush Key at most and can easily returm then finshed feeding.

Lengtir of Incubstion Sniets

To detemine the length of incubation shifts (the length of time one adult cares for the egs without relier), I recorded which adult incubated each day for most of the nests I kept activity records on. Usually I found that the bird present in the morning remained there until at least Iate aftemoon. Because nost aduIts seem to return and exchange in the early evening, I assumed this was tme unless I had evidence to the contrary. I have computed inclibation silifs as multiples of I-ỉy periods. I nay have missed a few exchanges but the pattem I found is generally true of incubation shifts at Bush Key. Watson (1908) also notes that nost Dry Tortugas Sooties return in the evening and that incubation siits generally are 24 or 48 hcurs Iong.

Of 231 incubation shifts measurad in this manner, 148 (64.J. Fer cent) were 1 day in length, 70 (30.3 per cent) were 2 days long, and only 13 (5.6 pez cent) were 3 days long. Figured differentiy, sooties did 45.3 per cent of their incubating in l-riay shifts, 42.8 per cent in 2-day shifts, and 11.9 per cent in 3-day shifts. Even though l-tiay shifts are nore than titice as comon as 2--day sifits, the two contributed about equally to inclibation.

Some pairs altemated daily throughout incubation, while others alternated regularly in $2 m$ day or, in a few cases, 3-day shirts. Otners seened to follow no set pattern of relief. Dverall on the basis of these records, males spent schenthat more time (175 to 152 days) caring for the egs than did femaies, but the difference is not stgnificant. 
$\left(x^{2}=1.62, \quad P>0.20\right)$. In the hourly activity records, naies again predominated ( 880 to 752 hours), the difference being statistically significant $\left(x^{2}=10.04,5<0.005\right)$. As the female left the egg shortly after laying and the nale cared for it on the first shift, some of this differencs occurred then, but even excluding the records for the first day of incubation, the male still cared for the eso more than the femaie.

Watson (I903) shows that incubation shifts on the Tortligas average somewhat over a day long with the longest a little over 3 days, well Withir the range I found in 1968. On Ascension Island incubation shifts average 132 hours (Ashmle, 1963), over twice as long as those on the Dry Tortugas. On Christmas Island in the Pacisic, incubation shifts are about 7 days long (Ashmole and Ashmole, 1967). Incubation shifts vary from 2 hours to 3 days on the Seychelles (Ridley anc Percy, 1958).

The striking difierences jn incubation shifts between Bush Key Sooties and those at two other colories are probably related to food availaoility and distance irom the island. Asmole (196́3) reports many young at Ascension dying of starvation one year, aprarently because of a failure in their food supply. On the Dry Tortugas Sooty Tem chicks have nerer been known to experience heavy mortality from food shortage (Pobertson, 196\%). No evidence exists to tie the almost total nesting failure at Bush Key in 1969 to food. The shorter inclibation shifts seern to indicate that the terns have an adequate food supply near the island.

InIiuence 오 Ueathen

The most obvicus efrects of weather on incubation patterns of Sooty 
Terms are the shifts from incubaring to shading and back to incubating, depending on the enviromental temperature (Figure 3). Sudden changes in weather provided natural experinents on weather effects. On hot dais when clouds rapidy lowe: the air temperature, shading birds quickiy change to incubating o: move away from the egg to preen or perfom other waintenance activities. Cree the ciouds pass and open sunshine retums, the birds again shade the esg. On nomal, clear hot days an aduit virtuaily never leares its egg between II:00 end 15:00 except to oip. The few recoris I nave of terns pexforming other maintenance activities during those hours nearly alvays occurred on clcugiv äars.

Rain also changes activity ratterns. At the start of a rainstom, swarms of Sooty Terns rise and circle over the colony, calling noisily. As nearly all birds that are caring for an egs incubate tirroughout the stom, it is primarily free bircis that circle over the colony.

Apparently Sooty Term feathers are not vater repeilent and are easily soaked by rain. After rain Sooties preen their body and flat their wings vigorousiy. This apparenty helps ther. dry the feathers to permit flight. Biròs have great difficulty taking off in eariy morning after a heavy dew has soaked their feathers. The ilncks of tems rising at the siart ô rainstors are probably birds getting airoome before they becore too waterlogeed. Once in the air, many remain there until the storn is cver, the motion of their wings preventing them from getting soared.

\section{Fledging Period}

Hatching

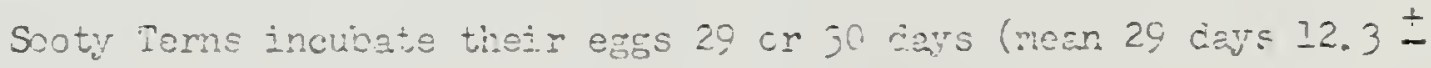


2.4 hours, range 28 days 22 hours to 30 dars for 16 eggs). This agrees well with Ashrole (1953) who found that ustially the egg is incubated 28.5 to 30 dajs. Watsor:'s (1908) figure of 26 days seem somewnat short, though Riniley and Eeroy (1958) say Sooties incubate for 26 to 29 days on tre sejchelles.

The chick mej pip the egg as much as 30 hours príor to hatching, but usualiy does so only the day before hatching. For eggs that I could detemine tine tine of hatching exactly, most hatched around sunrise or Eround ncon.

fidults attend ripped eggs very closely and seen reluctant to leave them. The only time that Sooty Tems ever actually mobbed or struck me in the colony was when eggs were hatching. Howell and Bartholomer (1962) show that such an egg is particularly sensitive to heat stress and has no effective means of dissipating excess heat. Thus care by the adult is especially inportant to insure the chick's survival.

Adults avpear indifferent to the presence of the empty egg shell in the scrape and sometines continue to sit on it after the chick has emerged. About 20 times I saw an aduIt pick up and carry ổ a piece of egg sheil, often one from a neighboring scrape. Usually adults allow the empty snell to roll around until it is finaliy broken and crushed.

Sooty Tem €డ̆รs (Iike those of most terns) are speckled and carnouflaged on the outside, whereas the white inside lining contrasts sharply with the sand background of the nesting colony. Tinbergen et ai. (1962) show that rapid removal of the empty shell has definite survival vaiue for Blaci-neaded Gull (amus ridinunciss) chicks. In a colonial species like fuscata, removing the egs shell probably makes little 
difierence to chick survivai. Any predator that reached the colony would have little trouble finding a chick, whether tine rhite inzide lining of an emoty egs marked the screpe or not.

\section{Attentiveness}

Yy data on varental care of chichs are less complete than those for care of the $\epsilon g g_{\text {. Every }}$ inine I entered my blind, the cinicks more than a fer days old scattered and hid under the nesrest cover. It sometimes took several hours for them to retum to thein scrapes where I could watch them again, and some never returned.

The records I do nave, sumarized for the first 2 wesks of the chick's life, indicate that the adults are most attentive during the midday nours, mich as they were when caring for the egg (Figure 4 ). As in incuoation, adults rise up oft tine chick to shade it in hotter hours of the day and brood it when it is ccol. Females care for tine chick somewhat mone than maies ( 157 birchours to 132 birä-hours), but statisticaily tinese are not significandly different $\left(x^{2}=2\right.$. ló, $\left.p>0.10\right)$. I found little difierence oetreen meles and ferales in care o: chicis and I nave combined the records in Figure 4.

Generally adults are less attentive when caring for tre chick than when caring for the ez5. They often stand to the side of the chich for an hour or more, and their attentiveness decreases as the chick grows older. After the chick is about 3 reeks old, the aduit spends very little tire actually caring for it other then feeding it, althoush they may stand near it during the day. Fron then on cricks even seen to spend the night unibrocded by an adult. 
Figure 4. Activities by adult Sooty Terns during the first 2 weeks of caring for the chick. 


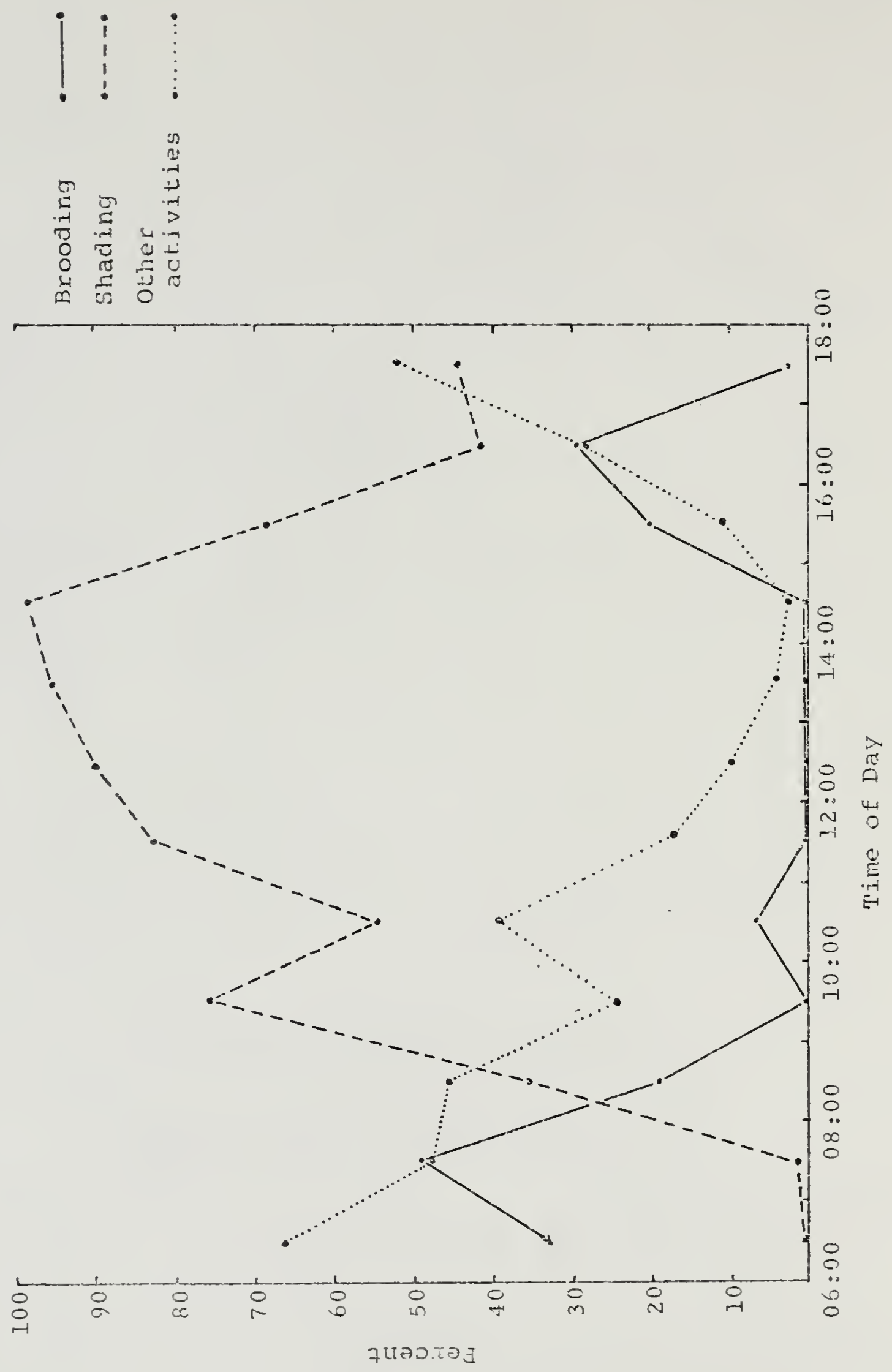




\section{Feeding}

Chick care centers around the provision of fcod. Sooty Terns apparently feed ainost exclusively on fish and squid (Astrole, 1963; Ashole and Ashrole, 1967). Much of this food is caught, when schools of tuna, makkerei, or other large predacious fish artve maller fish to the ocean surface. There the Sooties dip down to seize food from the surface or in the aj.r aoove it, but seldorn dive headiong into the water for their prey as mast other terns do (see Ashole and ishmole, 1967).

In the detailed study by the Ashmoles (1967) on Christmas Island in the Pacific, fish make up about to per cert of the food itens and. squid 40 per cent, with tha figures reversed when volume is measured. Flying fish (Exocetidae) and tuna (Scombridae) are two of the most important fish along with snake rackerel (Gempylidae) and bonnetmouths (Enclelichthyidae).

On the Dry Tortugas Sooties have been raported eating fisi of the families Carangidae ard Cluceidae (Watson, 1908). A variety of regurgitated fish have been found in the tern colony (Longley, 1929; Iongley and Hilcebrand, 194I; see Erdman, 1967) but none of these Iists separates what was taken scecifically by Sooties. In recent years Robertson hes collected many fish and squid that Sooties and Noddies regurgitated when mist-netted. it present only the Scombids have been analyzed (Jottheff art Richards, 1970).

I saw one chick fed about 4 hours after hatcining, and they may be fed even earlien. The adult stands near the chick and points its bill down. The chick then either grips and bites the adult's bill or Eise pecks at it. The chick may also beg with some rapid "cheep" cails. 
This action seems to release regurgitation by the adult. The aduit stretches its neck ard head upward, tips the bill clown, gago, and then brings up a fish. The adult mav hold the fish in its kiII before Peeding the chick, or it may slice the fish directly down the bill and into the chick's molith. Sooty Tems were never seen retuming to the colony with fish in their bill, but aivays carricd the fish in theis esophagus and regurgitated it for the chicks.

Older chicks seened to beg more oy opening their biIls and giving rapid "cheep" calis than by pecking at the adult's bill. They also grabied at the fish while the adult was stili holding it, sometimes leading to tugs-on-iar betineen the tro.

In neerly every case where I could see ciearly the exchange of food from adult to chick, the fish was regurgitated and passed to the chick tail-first. lany of the fis appeared to be scaleless, and in some cases tiney were partly digested or fractented, especially the last ones passed to the crick (presumabiy the first ones the adiit caught). The regirgitatea food is often ccated with mucous. Tnis may retard digestion of the food as the adilt carries it back to the colony (Ashmole and Asinole, 1967).

A chick migit get six or more fish in one feeding, depending on the size and degree of digestion ồ the food. Several times I san an adult feed a chick six times in 3 to 4 minutes, each time passing one fish. Other times a whole meal might be one large bolus containing several fish.

OI 349 occasions when I cefinitely saw a chich fed, the majority occurred fron $06: 00$ to $10: 00$ and from $16: 00$ to 18:00 with many of the rest occurring just belore or after those periocis (Table 5). Passing 


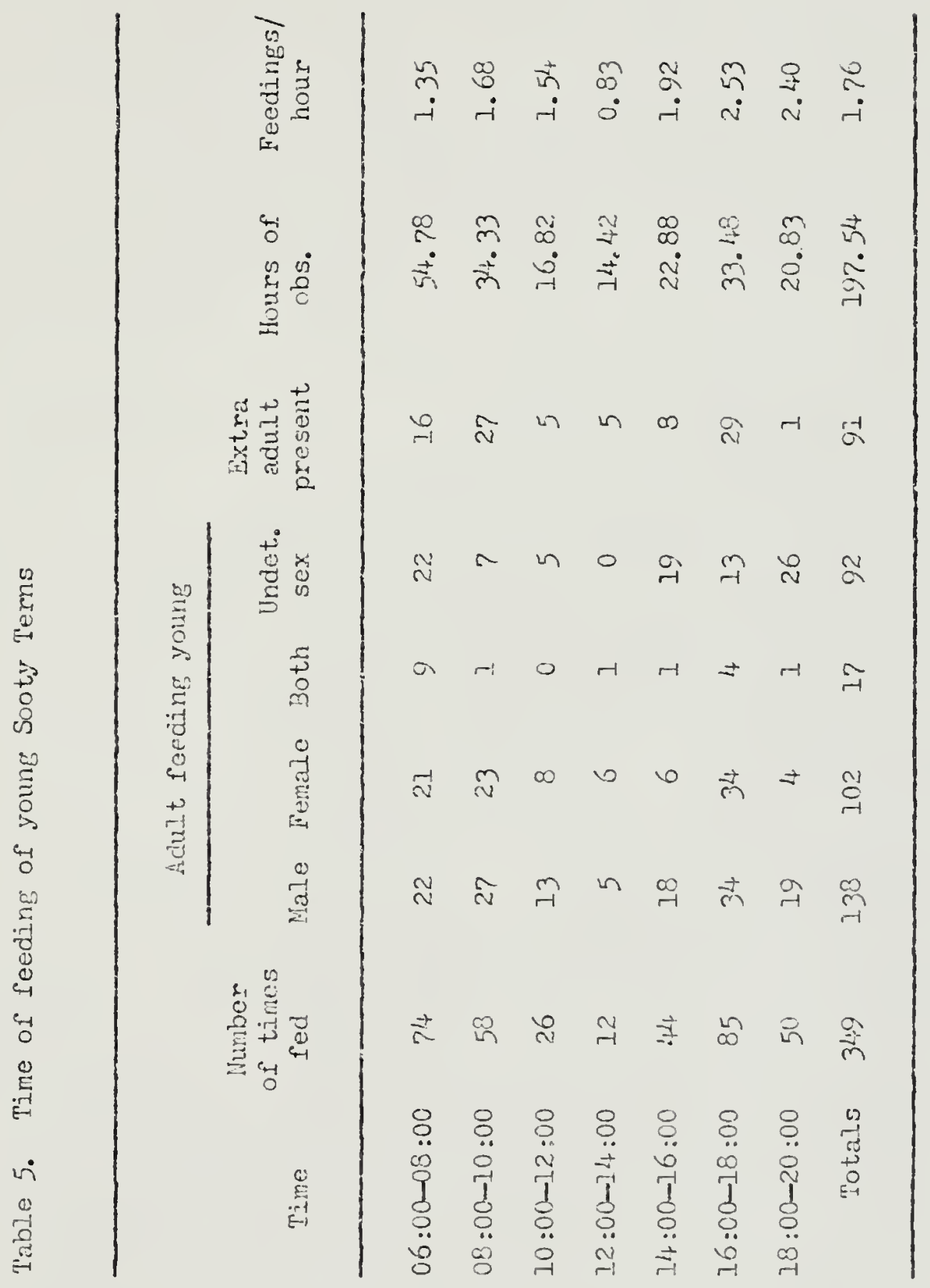


several fish to a chick in the space of a ien minutes is counted as one feeding. Is the number of observation hours varied during the dat, the number o: feedings per hou of observation (Table 5, Iast colum is a more valid comparison. Tois shows that peak chick feecing occurred in late aftemoon enc eariy evening witin a smailer peak early in the morning. These obsemations were made from 16 Nay to $10 \mathrm{JuIy}$, the time when chiclis were present on my ylot.

In about 5 per cert of the feedings, both acults fed the chick; far more commonly two adults iere present but cnly one actually fed it. Of 240 cases in which $=\mathrm{knew}$ the sex of the bira feeding the chick, the male did so more often than the female ( 138 to 102) and the difierence is statistical?y significant $\left(x^{2}=5.40, F<0.025\right)$.

In adcition I recorded some 240 occasions where a chick begged ano an acult tried to feed it without actually doing so. Sometiries the adult regurgitated and heid food in its bill and then reswallowed it, even when a chick begred loudiy. The adult might do this several times, but usually eventually red the chick. Other times an aduit tried to regurgitate but was unable to oring up any jood.

The aduit piaces all food cirectly in the mouth of very small chichs. Any that drops on the ground remains there unless an aduIt picks it up to eat or seea to the crick. The youngest crick to pick up food from the ground was about 2 month old, but they may do so when younger. These older chichs pick up food from the ground on scraces other than their own. Cnce as an adult held a iish in front of a chick, I saw another aduli seize the fish and stalicio it. 


\section{Frequency of Feecing}

Sooty Terns on Eush Key feed their young infrequently enough to make it difficult to obtain good information on the rate of feeding. Although I watchec many chicks continuousiy for long periods, I have few good records of an adult feeding it, leaving j.t to forage, and returning to feed it again. A major complication is that rather than imediately giving a chick all the food it has in its esophagus, an adul.t may feed the chick severa? times over a period of several hours. I sars cne aduit regurgitate and feed its chick some 5.5 hours after it retumed to the colony. Thus if an acult fed a chick, flew asay and retumed in 4 or 5 hours and fed it again, I colla not be sure if the adult had left the island to forage in that time or if it had just Ioafed eisewhere on Bush Key before retuming to the chick. Consequentiy I have deterwined the rate of feeding two ways.

I have five gocd records of an adult leaving the chick and returning later to feed it. These were all made on 26 Way with chicts 2 to 8 davs old. The length of time the adult was aosent (foraging time) averaged 3.87 hours and ranged from 2.63 to 5.30 hours.

I also tabulated the number of times chicks vere fed during long periods of continuous obserration, separating these into chicks up to 15 dajs old and ones 15 to 27 days old (Table 6). After listing the total nurber of times the chich vas fed, I subtracted those extra Feedings that cccurred when an adult fed a chich more than once after returning to Bush Key. Inis gives the probabie number of foraging trips made per birdwhour of onservation and gives a rough estimats of the time an adult spent foraging, about 3.44 hours. hpparently forauting trips are about an hour longer when the chicks are older, 
Table 6. Rate of foraging by adu?t Sooty Tems

vimber Probsbie

of nube: of number of hours ver Age of chick fesdings foraging inips of coservation foraging trip

\begin{tabular}{rrrrl}
$1-15$ days & 144 & 113 & 369.42 & 3.27 \\
$16-27$ davs & 20 & 19 & 84.58 & 4.45 \\
Totais & 164 & 132 & 454.00 & 3.44 \\
\hline
\end{tabular}


but the sample size is srali and the adults may just loaf part of the time. Note that here time is in bird-hours of observation whereas in Table 5 it is hours of obsemation, during each of which I watched about 15 chicks.

The tiro estimates are close enough to indicate that Sooty Terns at Eush Key probably forage 2 to 5 hours when they are feeding their chicks. Ádults seem to pass food to older chicks noje rapidly after they return to Bush Key. That is, rather than standing with the chick and feeding it several times in a few hours, they seem to seed it all the food they have and then leave it.

Often I saw exchanges that appeared to be after foraging trips of 4 to 8 hours but the birds ray hive exchanged in short intervals when I was not watching. Thus my recoro's of foraging time are biased for shorter periods. Watson (1908) gives 4 to 7 hours as the intemal. betreen feedings by Dry Tortugas Sooties, consistent with my rindings. Sooty Tern chicks on Bush rey are fed much more frequentiy than those in other colories that have been studied. On Ascension Islend chicks are probably fed about crce a day (Ashmole, 1963). On Christmas Island chicks are probably fed every 2 or 3 days (Ashole and Ashmole, 1967) but good inforiation is lacking.

As the chichs grow, the adults become less attentive and cften gather by the hundreds on the Bush Key beaches and sun much of the dav. Other adults soar over the island during the hotter tiries of day (see p. 62). Perhaps adu]ts away from thein chicks spend part of their time in these groups. They must spend sone of their time foraging but exacty how much is difficult to determine.

At Bush hey more aciuls are present and the colong is noisier in 
the evening than at an other time of the day. Hence I think that both adults are probably at the colony at night, though both may not be with the chick at all times. Elsewhere Sooty ferns feed at night at least cccasionally (Bmyns and Voous, 1965; Gould, 2967), but at Bush $\mathrm{Key}$, with the noticeable influx of birds in the erening and exodus in the morring, I doubt that many adult,s feed at night. As during incubation, mist-netied birds regurgitate far nore frequentiy in the evening than at other times,

The average Plight speed of Sooty Terns is about 2 ? mph (Suhrell, unpublished). Thus on Ionger trits they nay forage as much as 100 ailes from Bush rey, but the average foraging trip of about 3.5 hour's gives them a range of about 4 miles. Sooties from Bush Key usuaily fly toward the west when they leave the colony and return from that direction. How far they go is unknown but they easily could fily to the nearby Florida Current and feed there.

At about 3 weeks of age, the chicks begin to warder from their scr'ape. They may soend muci of the day alone, being accompanied by an adult mainly when being fed. Some adults seer to check on their chick periodically during the day, landing beside it, possibly feeding it, and then flying off only to return in an hour or so. These adiits prcoably spend mich of their time loafing on the beaches or soaring.

I was not able to visit 3ush hey during the height of Iurricane Abby ( 3 June) but on 4 June it was obvious that the tem's ncmal schedule had been dismpted as fer adults were present until that evening when they started to strean into Bush key and continued to do so until the evening of the 5th. They prcobly had been unoble to feed curing the storn and had left as soon as possible to chtain pod 
for themselves and their chick. Nason and Steffee (1966) noted a similar dismiotion after furricane Alma.

\section{Individual Recosnition}

As the chick: grows, its prysical appearance changes and it may wander farther fron the scrape. As the colony has thousands of chichs, adults undoubtedly have problems locating and feeding their own (or adopted) offspring. Sooty Tem chicks and adults evidently leam to recognize each other so the chick car be located and fed.

Wuch as Lashley (1915) and Burckhalter (1969) report, I Iound that parents apparently do not recognize their chicks individually at first. In the first 4 or 5 days chicks often return to the wrong scrape and are readily accepted and reared by foster parents. After that they are pecked savagely if they intrude near another scrape, and some are killed. This adults seem to recognize their chicks when they are about 4 to 5 days old. As Davies and Carrick (1962) and Hutchison et, al. (1968) suspect for other terns, this recognition probably is based on cails between the adults and chicks.

Aiter a disturbance, typicajly the adult tries to atiract its chick back to the hore scrape with a combination of bill novenents and low calls. The call is a low two syllable "kraa-unk" note accompanied by bowing movernents of the bill and head, ending with the bill pointing down toward the breast feathers. Often an adult used such behavior to lure the chick back to the scrace, backing away from the chick and toward the scraoe until the two were finally back at their own scrape. Once I watched an adult nold a fish in its bill and back away from its chick, apparently using the fich to lure it back to the 
By 3 weeks or age nost of the chicks on my plot spent nuch of their tine niding under the nearioy bay cedar. Sy removing nost of the vegetation from the nesting plot I may have forced them to nove to this cover. Typically these olaer chicks emerged from the bay cedar late in the aitemoon and stood at its edze or ran out to their scrape. The chicks ran swiftly to a spot and stopped, seemingly knowing where they could stop and not be attacked by other chicks and aduits. Once on the scrape, trey stood and waited for an abult to come and feed them. Winenever I caught one of these chicks, it ras always at the scrape where it had been reared and this had "honed" correctly. Also when an adult fed the chick, nomally the aduit was one of the pair that had used that scrape. Hence the chicks apverentiy knew their home scrapes and retumed there to be fed by a parent. Sometimes the acult landed at the scrape before the chick ammivec. Then the adult typtcaily circled 10 to 15 jeet crer the scrape and delivered loud "widik" or "kawici-ik" notes from the air until it was ansuered by a loud piercing "che-up" call from a chick hicien under vegetation. The trio birds exchanged calls several times and the aduit landed. The chick trien ran out to the adilt, begsed, and vas fed. As the chick approached the acult, the aduit orten gave what appeared to be a greeting, flying stiaight uo 2 to 5 feet in the air, giving a loud "wide-amite" cali at the peak, and dropping back dom to the ground to feed the chick. These "fly-ups" occurred in other situations and are discussed later. Occasionaliy the adult pecked the begeing chick sharply. I was not able to deterine the relationship of the tro in these cases, but I suspect trat the tro hac nade a mistake in recognition and the duit cidd rot realize it until the cinck came close. 
Although cricks are usually fed by their pareints (or by adults that adopt then), at least eight times $I$ saw a tern feed a chick other than its own. In five of these instances an adult that had lost its chick or whose egs had failed to hatch fed a chick, usually at an adjacent scrape. Three times an unmarked adult fed a chick whose parents were both marked and thus recognizable.

I aiso saw some chicks that seemed to approach and beg to any adult that cane near. Although these chicks were not narked, I ani fairly sure that some were fed by aduits other than their parents. Oiten the adult pecked the chick and drove it avaj, but often the aciult tried to regurgitate. Occasionaliy it was successful in bringing up some food that it then fed the chick. Fossibly these chicks had lost their parents in the shuple of chicks in the first feu days of life, and no adult recognized them as its cwn. The adults that fed them or tried to feed then may have been their lost parents, or other adults that had lost their chick or egs.

Thus older chicks seen to find their parent both by knowing where the home scrape is and by recognizing the aduit's voice. Although I think Sooty Term adults and chicks do recognize each other indiviaualy, I believe that much of this recognition is done by the adult, while the chick may try to get food from alnost any aoult that cones near.

\section{Chick Behavior}

Sonty Tern chicks can walk almost inmediately after hatching and stand and beg for fock mithin 4 hours. For the pirst, few days they are closely brooded by one of the parents, the chict resting either between the perent's feet or crussways in front of them, At first 
they walk by hall crouching with the body low and almost on the ground, but they soon walk upright like adults. After a disturbance these small chicks freguently end up in the wrong scrape. I often saw two small chichs under one adult that seemed to accept both of thern. The extra chick eventually retumed to its own scrape, usually when called by an aciult. A comon alarm response of these small chicks was to lie flat on the ground with the head and bill extended forward. Chicrs apparentiy did this to avoid being pecked by aduIts, as adults pecked viciously and sometines killed strange chicks that came close. Chicks 5 days old preened and voided with movements typical of adults. For the first 2 weeis, one adult nearly always stays at the scrape with the chick. During the 3 rd week this attention gradually djminishes, and by the end of the 3 rd week the chick is often alone. Chicks defend the scrape, pecking at and driving off other chicks and Brown Nodies that intrude.

Nost chicks stay close to their scrace until they can fly, but older chicks that wander or are moved can find their way back to the scrape when displaced several hundred feet (Burckhalter, 1969). Chicks from scrapes close to the beach may sun and rest with adults in large flocks on the beaches during the clay, and then disperse in late afternoon. Generally the chicks coneregate just above water level ind the adults assemble higher on the beacin. Perhaps the sand is cooler there then higher on the beach. I did not see adults feed chichs in such flocks. Apparently chicks retum to their home sarape or some other nearby place to be fed.

1 observed G-reek-old chicks juming into the air and flaping their wings vigorousiy. I lack exect records of when they begin to 
fiy, but one chick flew several hundred feet on 4 Juiy and others were doing so wtinin a week. If that chick had hatched from ore of the eggs laid on 1 Auril (it was in that part of the colony), it would have been about 9 reeks old, the bast estimate I have for the age Sooty Terms begin ilying at Busin Key. As noted by Ashnole (1953), chick development varies with the food supply. One rear he found chicks at Ascersion flying when about 8 weeks old and the next year, when food apparentily was scarce, birds around 9 weeks old. still could not fly. Burckialter (19óg) sair E-itek-olè chicks flying on the Hewaitian Islands, but he says they stayed a.t the island another 2 to 3 wee!ss.

Most of the chick's activities before it starts ilying seem to be related to feeding and temperature mainterance. Ooviousiy the adilts help with the latter when the chicks are srall, but $3-$ to liriteek-old chicks start assuning their juvenai plumage and are laröely independent. When placed in con sunifint, their body temperatures rise to the lover range of black bulb temperature and then level off (Howell and Bartholone: 1962). Chicks may holp stabilize body temperature by panting, facing aray from the sun, drooping the wings, and erecting the back feathers, much as adults do when it is hot. A fon of ry tethered chicks died in open sun when about this aze, apparently from heat stress. Thms body temperature must closely approach lethailty when chicks are exposed to open sur. Jupeniles seem to leave the colony soon after they learn to fy, as there selcion are many flying juveniles at Bush $\ddot{i} e_{\mathrm{y}}$ at any given tins. As the do not feed near Eush Key, little is know of their. activities. In all probability, the adults stav with the ycurg and 
continue to feed it urtil it can capture food by itself (Robertson, 1964; Burckialter. I969) as co acult Royai Terns (Astrole and Tovar,

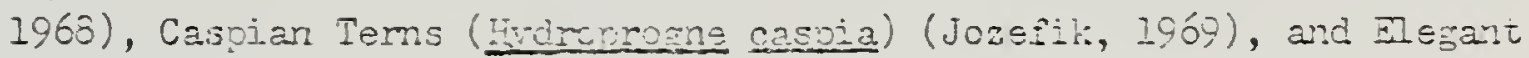
Tems (Mnalassous elozans) (Nonrve, 1956). Jush Kej adults carnot feed flying Scoty Tem young more than about 2 montins though, as the juveniles leave the range of ajuits by about October (Robertson, 1969). This certainly must be a difficliit time for young Sooties as they must learn to capture Iood wille on the wing, a skill regiiring good eyesight, coordination, and timing.

\section{Other Aerial Activities}

\section{Thermal Soarinc}

Sooty Terrs ai Busin Key comoniy soar in dense circling cclumis during midday nours on not deys. Fossibly at these times updraits or thernals develop nean Bush hey. The columns epproach 200 feez in diameter and sometimes go iron just above sea level to severai hundred feet in altitude, aithough most bisis are usuaily below 20 is it. Within the colums the biras circle as they climb and then soar off to join another columin. Nost comon lats in the breaing season, thess columns of scaring bircis are tailer than the oircing flocis seen earlier, and the biras aiso apear to fly iaster tian in tine eariy season flocks. Jsually tire terls are stient as they soar but occasionaily che gives a "wich in" call.

Soaring often continues for several hours although the compositirn of the floci changes as birds join or leave it. The colums otten move laterally and two ray merge into a single colum. Uagnificent

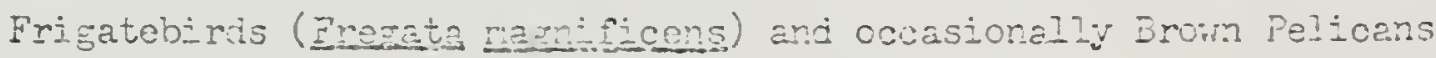

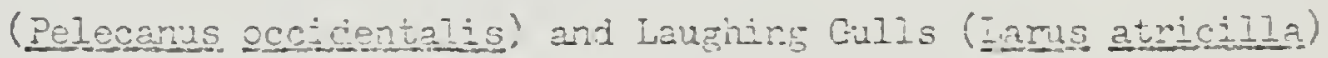


(Harrington, pers, comm.) join these flocks, but I did not see Brown Nodaies do so.

\section{Fiv-ius}

A rather common activity in Scoty Tem colonies, especialiy when chicks are present, is for one or more adults to fly straight up 1 to 5 or more feet, give a loud "wide-a-wake" call at the peak, and drop back to the ground. I call these flights "fly-iups," and I believe they are a type of social behavior, often used in greeting. Besides the birds that actually fly, other birds around then often raise their wings verticaliy orer the bodr in a flight intention movement, but do not fly. These fly-ups usualiy involve a small group of terns. During a Ily-up, other nearby birds becone very active and noisy for 15 to 60 seconds and then gradually quiet dom.

During incubation, I saw fes fiy-ups. They usually occurred when an adult arrived at the colony to assume care of the egg. Other adults near the arriving tem's scrape might fly up, seemingly in excitement over the arrival of another bird at the colony. Burckialter (1969) also saw this group activity when an adult arrived at the colony. Once the chicks were present, I often saw fiy-ups inen an adul.t lanced to feed a chick or had started feeding it. Again several adults flew up in the air in a sudden burst or activity and then quieted down.

Fly-ups were rather common when the chicks got fairly laree. Then I often saw acults fly wip when a chick ran out from cover and anproached them. As the chick approacheri, the adult flew up, called and then lancied to feed the chick. In theso instances the chick seemed to stinulate the riyn. Several. times I sam a chich run past several 
adults, each one Plying up in tum as the chick approached, until the chick finaily ceme up to an adult that fea it. Thus the aruits seamed to react as if the chick was their own while the chick went by and approacheo anotiner adult, presumably its parent, to be fea.

\section{Panics}

Sooty Terws exhibit tro distinct types of disturbance filghts, commonly carled pantos. Of trese, dreads apparently incude the flights Palner (1941) cails creads and panics for Comon Tems while those temed alams are similar in botin species.

Max. - -inen an intruder openiy approaches the colony, the birds stand upright rith the neck and head stretched vertically. As the intruder cones closer trey $f l y$, calling as they do so, and then circie and hover over the intruder until it leaves the vicinity of the scrape. Unlike many other texns, Sooties seldon actually struke an intmaier, out rather hover near it or dive at it without striking it.

I did see Scoties attack Cattie Egrets (Bubulcus iois) and once a Purple Gallinule (Porphyrula martinica) that had broken a tein eas. Then the Sooty landed on the gallinule and jaobed it. The ifir.times a Sooty Tern struck me occurred about the time the eggs were natching. A lcud, long 21 arm call, usually a downwar inflected "kee aa" or "kerr az" often precedes the aiams. Host alams are quite local, involving relatively fe:; birds in the colony. Occasionally though, tiney soread throushout the colony and virtually ail of the tems fly. Alarms seen to start from an intrusion that is not sudien, but anticipated for a short time. The circling and cailing by Sooties curing rain are nrobably just a fom cfi the elamt. Ctiner disturidunces are caused by les: tancible paotors such as a loü sound (e. S., sonic 
boor, boat whistle) or a sudden movenent. These elicited a different response - the dread.

Dread.--In dreads the tems suddeniy besome silent and fly rapidiy from the colony to the water, carting and swooping as a unit silently down lor over the water. At the end of the swoop, they rise up, start cailing loudly, and graciualiy drift back to the colony. Thus if a bird is on tine ground when the dread starts, it files rapidly out. over the water, and those birds that are already in the air suddenly swoop out over tile water. This seers to be a high intensity form of panic.

One final, coorly affineo alarn reaction is that ir which virtually the entire colony Ilies up from the ground, either at once or, more often, in a graduzlly spreading froup from one end of the island to the other. In the air the birds call loudly and drift out over the water and then fracually move back to the colony. This delayed alam seems to stant as an alam in one part of the colony, and as those birds fly, they scare up birds near them and so on until the whole colony is in the air. 


\section{ECOLCGI}

\section{Interactions with Other Soecies}

\section{Enenies}

As their nest on isolated isiands, Sooty Terns come in contact with relatively few verteorate predators. Those predators that reach the nesting colony find eggs and chicks plentiful and vilnerabie. Adult Sooty Tems are fast and shifty in flight, and probacly few other birds are capable of capturing a slying adilt. Certainit the most serious natural predator on Bush rey is the Peregrine Falcon (Felco rengrinus). Cne and occastonally two peregrines vere present at the Dry Tortugas from 8 to $I 1$ Arril 19,63. I saw a peregrine stoop at Sooty Terns 23 tines irthout capturing a bird, but I did find the decapttated renains of four sooties that the falcon had almost certainly killed. I nave seen ceregrines caoture incubating Sooty Terms on Little Tobago in the southern Hest Indies.

On 15 ilay 1968 a Furple Gallinule cracked an egs and ate the contents until a Sooty attacied and drove it aray. In iune, 1969,

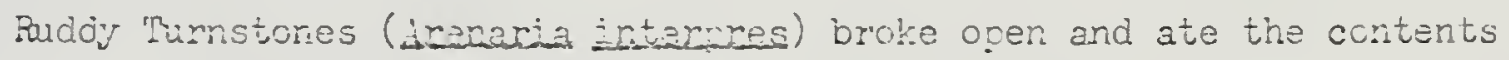
of several unattended egss from which I har. Irightened the adult sooty Tern. Normaily the acult terms sit tight if a turrstone aporoaches, but turnstones can cause considerable nortality among unattonded egss.

The lagnificent Frazteorlis periaps the greatest threat to Sooty Tern chicks. Frigatebird redation must vary considerabiy from year to year as in 1968 - saw one capture a Sooty chic's only once 
(3 June) while other years they have taken many chicks (Beard, 1939; Sprunt, 1946). When frigatebiras do prey on tern chicks, it seems to be a prey preference of only a few individuals ratiner than of all the frigatebirds present (Robertson, pers. comm.). On 24 Viay 1968 a frigatebird chased a Sooty Tern adult. They may occasionally steal food from the terns. Ashnole (1963) revorts Progate acuila taling many yourg Sooty Terrs on Ascension Island and $\underline{F}$. mincr does the same on Christmas Island (Ashrole and Ashrole, 1957).

Frigatebircis usually take only smali chicks, mainly in opon parts of the island where they can not find escape cover. Thus the relatively thici vegetation on Bush Key in 1968 probably discouraged frigatebird predation.

\section{Predation by rats (Rattus rattus) aiso must vary from year to} year. I saw no evidence of predation by them in 1968 but in other jears they have been a serious predator (Russell, 1938) on Bush Key. Several times an Osprey (Pandion haliaetus) circled over Bush rey but usually the terns ignored i.t. Once several terns mobed an Osprey. A few other times the birds panicked, but it may not have been due to the Osprey's presence. The only other hawk I have seen cause any atam was a Broad-ririged Hark (Dutee xlatynterus) that circled Bush Key on Ló June 1969 and apparentiy started several panics. Other hawks nicrate through the Dmy Tortugas and occasionally may disturb the tems. Cattle Esgrets occasionally take a Soty Tern egz or chick on Bush Key (Pobertson, pers, com.) but more comonly just disturo them. Ridley and Percy (1958) report that Cattle Egrets often take Sooty Tem eges and chichs on the Seychelies. Of the Cattle Egrets that migrate through the Dry Fortugas, those that linger generally are unaile to 
find enough food to maintain their llying strength and eventually starve to death. This shortage of food apparentiy forces tinen to feed on almost anything they can Iinc as they orten tale small mizrant passerines (Cuningran, 1965; pers. obs.). They also feed on fish the tems drop and on inseats, disturing the tems as they feed.

Typically as an egret approaches a tern with an egg or sicick, the tem faces the egret and gives a series of low, hoarse "huik whik notes. As the egret cones closer the term raises up off its egi or chick, erects the feathers on the top of the nead and contimues to diract "wuk" calls at the egret, the calls becoming lcuder and more racid and often changing to a rapid "ka ka ka" call. If the fegret comes within a few feet of the tern, the tem slies from the sorape and circles over the egret until it departs. A fer times a tem stretched its head and bill forward, raised the wings almost verticaliy over the back, and ran at the esret. Sooties scretimes dive at an egret but they seldom actuaily strike it.

Cattle Easets often fly low orer nesting terns, eliciting a lors, dram out "kaa." note from the terms ard sometimes starting a panic. The Sooties often chase egrets in the air and dive at them, mobbing them more comoriy in flight than when the egret is on the ground. Browin roddies frequently join the Sooties in these attacks on Cattle Egrets and the loddies are much more agresessive, striking tinem on the ground and in the air, and chasing ther farther than the Sooties oo. Cattle Egrets harm Sooty Terns mainiy by disturoing then and keeping the adults atway from the egg and chick, which can be fatal to the young tern. The Great inje Feron (andes cccicientalis) has been reported preying on Socty Tems on the Tortugas (Rubertson, :0,03). 
A few Herring (Larus argentatus), Ring-billed (I. delawarensis), and Laughing Gulls frequently linger arourd Bush Key. Gulls ccinonly prey on terns (Hatih, 1970), but. I never sas one enter the colony at Bush Key to prey on tem chicks or eggs, although they could do so easily. Watson and Lashley (1915) saw Laughing Gulls prey on Sooties on Birci Key.

Adult Sooties may peck and kill chicks that wender away from their scrape and can be a serious cause of mortality.

Ghost crabs (Ocroode quedrate) occasionally prey on tern chicks. A few times a tem gave a "wlik" note as a crab scuttled by or pecked at it but usualiy they ignored the crab. They also seemed to ignore the hemit crabs (Coenohita clypeatus) that probahly feed only on dead chicks and broken eges.

Although most Sooty Tern coionies are on relatively isolated islands, man reaches many colonies at least occasionally and adversely affects nesting success. Tern eggs are still collected for human consumption at sone colonies (Cott, 1954; Ridley and Percy, 1958), but National Park Service protection has curtailed egging at Bush Key.

It is much more difficult to neasure mortality caused by human activity in the colony, but at tirles such activity must be very hamful. Every time I entered or left my blind, I disturbed the birds, Although they soon habituated to this and rapidy returned to the sorape once I was out of sight, I still caused mortality, both by stepping on eggs and by separating chicks from their parents. Such mortality is inevitable whenever a human works extensiveiy in a Sooty Tern coiony. Other disturoances such as sonic boor1s, boat whistles, and low flying airplanes may cause the birds suddenly to leave the island in a 
iread. However I did not see any or these disturbances keep the birds away from their sarare ton mone than a fer minutes unless they were repeated.

\section{Other Tems}

The intemelations oI Sooty Tems and Brom lodides on Bush rey are interesting. Trese tro species are aburdant and widespread in the tropics and nest together on meny islands. On Eush Ker the Srown Noddies nest orinariy along the ecige of tine bay cedar, but also in other Iow vegetation and occasionaily on the ground. Although some Sooties nest under the bay cedar, they alwajs nest on the fround and hence are usually vertically segregated fron the ioddy nests. ilost. Sooties nest in the open flat parts of the island cutside the bey cedar, agein separating then from the lloddies. Some lodites nest in Iow vegetation within inches oi Sootj scrapes. I often sam young of both species in such situations, so apprirently they can breeo. successfuliy in ciose proxirity.

Early in the nesting season Vodaies often searched for nest raterial on my study plot. In all 35 instances or direct supplanting betreen these syecies that I sai on my study plot, the Scoty drove cff the Noddy. In two of these a Scoty chick drove an adult lloddy ofi the plot. Generaliy the Sooty stretched its heac and nech forward, held the wings either tight against its sides or silghtiy away fron the body, and acivansed towand the Ioddy untiI the loddy retreated or itew. I never saw a loulu ilght bach or withstand the attack Iong. Cnce I heard a Sootir g̈ive a Iow grouling "urr" note as it advanced at a liodiv but usuaiy botin biere silent. The fert tires I watched For the reverse encounter, I sar iodaies drive of: jooties that had core too close 
to Nodidy nests.

Noddies arrive a.t Bush Rey at, about the same time as Snoties, but begin work on their nest almost at once rather thar having a pronounced period of rlccking as Sooties.do. In 1968 Noddies started laying somewhat after Sooties (10 April) and as their incubation period is longer than the Sooties' (35 to $30^{\circ}$ deys, Thompson, 1903), Noddy eggs hatched later than the Sooties' eggs. Young Noddies mature faster than Sooties and many vere flying by late June, well before most sooty chicks.

Both species feed in a similar manner, dipping dowr to eapture focd at the ocean's surface, aithough noddies occasionally plunge to the surface or rest on the water to capture food. The Ashroles (1967) show that Sooties and Woddies have very similar jiets on Christnas Island, but the Nodaies seem to feed much closer to the island. They also note that the ring of the Nodoy, broader than that of Sooties, perhaps gives jit greater maneuverabilicy and allows it to forage more efriciently near the island, whereas the narrower wing of Sooties enabies them to forage farther from theif colonies. At the Tortwgas Ioddes opten leed witrin sight of Garden Key, dipoing dom and capturing focd at the coean's surface. Noddies have incuvation shifts of 30 minutes to 5 hours, much shorter than Sooties. They feed their chick every 2 to 4 hours (riatson, 1908), slightiy less often than Sooties. Tre fact that Sooties virtualiy never feed within sight of Bush Key and the somewhat different foraging times, esvecially during incubation, suggests that the tro feed in different areas, much as they do on Christmas Island. The two species apparenty feed in different zones at other colonies in the Pacific 
and Indian Jeeans (Ashmole and Ashnole, 1967:65-66).

The feir inundred Roseate Terns at the Dyy Tortigas generally nest in habitat quite difierent fron that used by the sooties. In recent years they have nested in the coral rubole on Long $\ddot{x e y}$ and on the oper. sand on some of the other islands. When they have nested on Bush Key, it lisulily has been at the far east end away from most Sooties. Roseates usually arrive later than Sooties and in 1968 did not start nesting until mid-iay when Sooty eggs were hatching. The incubation and fledging periods of Roseates are much shorter than those of Sooties, so young Roseate Terns were flying well beiore any Sooty Tern chicks. Roseate Terms often forage within sight of Fort Jefferson and probably avoid conpetition with sooties by foraging in different areas. They dive from the an and plunge into the water, thus captiuring food trat is unavailable to the scoties.

\section{Nesting Habitat}

Although Sooty Terns nest throughout Bush Key, they nest in greatest concentration outside the bay cedar thickets and mancrores of the central part of the island. I set up five plots cutsice the bay cedar, each 5 yards square, and at 2- to 6-day intervals narked all the ezgs iaid on each. I usually visited the plots in late afternon. As the eges hatched, I banded the ohicks in each. To avoid moriality, I did rot fence in the plots, and thus I missed many chicks that rled as I approached. Hurricane kbby caused no appreaiable mortality on these plots.

The density of egzs on each plot is summerized in Täble 7. Plot. I was close to the beach and har a thick cover of Osuntie, Uniati. ard Cakile. Plot. 2 was rainly low grass with some Qpuntia on one 
Table 7. Nest censity and success in itre 5-yard-square pl ts on 3ush key in 1968

\begin{tabular}{|c|c|c|c|c|c|}
\hline PIC亡 no. & :o. egss & $\begin{array}{c}\therefore c . \text { eहssi } \\
\text { sq Jd }\end{array}$ & $\begin{array}{l}\text { No. ezzs } \\
\text { oroken or } \\
\text { intertine }\end{array}$ & $\begin{array}{l}\text { Winimum no. } \\
\text { chichs kncwn } \\
\text { to hatoh. }\end{array}$ & $\begin{array}{c}\text { Dead chichs } \\
\text { fourd }\end{array}$ \\
\hline$I$ & 75 & 3.00 & 18 & 29 & $i$ \\
\hline 2 & 161 & 6.41. & 21 & 91 & $\ddot{j}$ \\
\hline 3 & 62 & 2.48 & 13 & 33 & 1 \\
\hline 4 & 28 & 1.12 & 2 & 13 & 2 \\
\hline 5 & 131 & 5.24 & 18 & 90 & 200 \\
\hline Totals & 457 & 3.55 & 72 & 256 & 23 \\
\hline
\end{tabular}


side and about 30 per cent bare ground. The first eggs on Bish hey in 1968 were laid on this plot. Plot 3 had a thick cover of Soorobolus and spurge (Eumpria bucipliz) ó to 12 inches tall. The main cover on plot 4, 4- to 6-foot tall Uniola, probably made it cifficult for tems to drop to the scattered openings on the ground. Flot 5 had scattered Euncroina and Carile and numerous bare spots. The righast nest densities were on plots 2 and 5, both of which had scattered bare areas. This seems to be a major factor in deternining nest sites for Sooty Terns, as care sand is arcided. The terns aoparently require some featires such as plants or rocks as reference points for locating the scrape and as cover for the ahick. ishmole (1963) noted the sane thing on fiscenstor Island. The other three plots all hari a veiry thick ground cover ir which aduits probably could not dig an adeouate scrace. Yy data on dersity of egss are somowhat higher than those lised by others for determining Socty population densities. For instance, Sprunt (1948) used clersities ranging from 0.5 to 5 per square yard depending on the thickness of the vegatation, but he counted birds only once. Sooties arrive over an extended period and fill in space as some ezgs are broken or deserted. My counts, made over an exiended period, included these additional egss and thus increased the estinate.

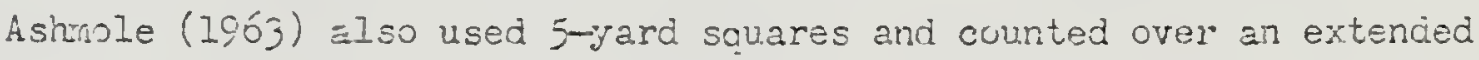
period. His maximum density of 132 eggs in a plot is sonewhat less than my maximum of $16 i$.

Ily data provide a rough estimate of the nesting success of souties at. Bush Kev. At least 256 of 457 eggs hatched, and probabiy rearly 385 hatched ( $45 \%$ minus 72 known broken or infertile). Thus somewhere between 56.9 and 84.2 per cent of the eggs laid hatched. is some pairs 
undoubtedly relaid ( $I$ often found a fresh egs next to ons of the deserted ones), perhaps 85 to 90 per cent of the breeding pairs on Bush Key procuced a chick. Ridey and Percy (1958) report that 82. 5 per cent of the egas at the Seychalles hatch.

Chick nortality is much harder to measire. Some chicks ran inio nearby thick ciumps of Countia and Suriana and I was unable to band many of them. 01 the 256 that I know hatched, I found 29 dead, a known mortality of 11.3 per cent. Chick mortality was undoubtedly higher as I could not follow chicks until they were flying and some older, more mobile chicks certainly disd without my knowirg it. As a rough estimate of total mortality, if 385 of tres 45 ? eggs hatchec and, of these, II. 3 per cent died, 341 out of 457 would be the naximum number surviving, a sumivorship of about 75 per cent. This of course assumes that all eggs that I did not find broken or deserted did hatch and also underestimates mortality of chicks. This is not iar. from the 70 per cent sumivorship Robertson (1964) gives as typical for Bush hey for sumers without hurricanes.

My presence on the plots undoubtediy increased mortality of eggs arld of chicks, and I see no way that it can be avoided if one woris with the biras intensively. Some chicks that ran from me probaoly did not find their ray back to their parent and starved or were pecked severely by aduIts and cied Irom the blows. Repeated disturbance also caused deseztion ol some eggs.

For example, I have gocd recoras of the numioer of eggs Iaid on my study plot ard the number of these that hatched. Of 122 egiss. 93 ( 76.2 per ceni) hatched, somewhat less than the marimun figure arrived at on the otiner five less frequently visited plots, but 
certainiy not inconsistent with it in consideration of the rariables in that information. Gully half the eggs that did not hatch were those closest to my blind, the cnes that I disturbed repeatediy.

\section{Siste Tenacitir}

Site tenacity, the tendency for a bird to returm to the same rest site year aiter year, occurs in the Comon Tem (Austin, IGLC). As I cclor-bancied I82 Sooties at one Iocation on Busr rey in 1968, Iater sightings of these provide sone information on site tenacity. I Iater sar 106 of the 182 (58.2 per cent) in the genexal area of cancins, and most of them prodaily nested in that general part ci tre ccionv.

From 28 April to 2 Say 1970, 0. I. Austin, ir. sat inr several hours each day near the olot where the terns had been oancied to watch for and record color-jancied birds. He san at Ieast 100 birds with color bands on the plot or imediately adjacent to it. I san thrae more in june and july, and three others were caught in oticer parts of Bush kej. Of the 103 birls on the plot, 76 could be icientified individually; the others had lost some of the bands and rere not caught to read the F.IS band. Of the 76 individually recognirable Scoties, 53 (69.? per cent) were among the 106 that had been seen on the plot in 1963 aiter bandins. Thus, of 106 colormaried birds trat probably nested on or near the studi plot in 1968, at least hif cf then ( $530: 106$ ) vere on the seme jlot 2 years later, The 30 birds that could not be identified inöividually may weil nave included biris that nested on trie plot in 1968. Thus 50 per cent is a rinimum Iigure and pornevs 70 per cent is a more neaningful. estinate of site tenacity. These data suggest that individual birds had a strong tendency to nest. in the same paris of Sush Key in 1909 ard 1970 . ¿.s 
my plot and the ground immediately around it covered much iess than I per cent of the habitat suitable for Sooties on Bush Key, it seems unlikely that by chance alone so many colomoznded birds would return to this same araz in 1970.

Site tenacity impies individual attachment to a specific locale in the colony. Croup adherence implies that subgroups exist within the colony and these subgroups stay together and individually recoznize other members of the group. Austin (1951) describes such sibgroups in Comon Tems and they ray well exist in Sooty Tern colonies. Young Sooties, if not allowed to return to their scrape, establish a spatial arrangenent with respect to other chicks similar to the patterm that, existed when they vere at the home scrape (Burckhalter, 2969). This implies that ther recogrize other chicks around them and act as a group. The Ily-ups already described also suggest that subgroups exist in Sooty colonies. In these, adjacent birus react to the actitities of one bird, seemingly as is they recognized one another.

Subgroups that move together within the colony could also explain the clustered nesting of colombanded birds seen at the plot, in 2970 , but this implies a faily sizeable group of dernaps severai hundred birás functioning as a subsroup. Aithough I definitely think subgrours exist in Soty culonies, site tenacity remains the rore likely explanation for oirds nesting in the same general part of the colony in two different years. If individuals repeatedly nested in the same part of the colony, they wculd of necessity contact the same birds year after year and then possibly form subgroups. 


\section{DISCUSSTCN}

Two broader aspects of sooty Tem behavior are particuiariy importart and iareant Iurther discussion. Finst is the comparison of the beharioral repertoire os fuscaia to that of other species of terns, especially those within the gerus Sterma. This should clarify tre affinities Sooties have with other terns. Fortunately, severai other terns have been studied careiulij encugh to provide a basis for comparisor.

Equally important are the acietations of fuscata that have allowed it to survive and thrive in a peiagic environont. 3y feeding in pelagic waters, Sooties differ considerabIy from most other tems and in rany ways closely resemble pelagic species of birds in other orders such as the Eroceilariiformes.

\section{Beiavioral Comparisons}

Behaviorai comcarisons can ise made with severai otrer temerate Sterna tems, the inite Tem (Gvis alba), the turo Anous. several species of Inajasseis, and the Black Fern (Chlionias niser).

The high flights of the Comm, irctic, Roseate, and Sarkivich Terns are ail quite similar (Cuilen, 19óca). The nigh flights cf the Caspian Tem and Black Tern resemble those of the others, althougi in niger many birds may ascend togetior. The circiing ascent and glicing descent of the Sucty fern ifigh flight are almost iciertical to thos of the Comon and Arctic Fern described by Cuilen (1960a). In the high 
flight of the Grown Noddy the ascent is somewhat like the upward flutter of Sooties but the birds descend in a circling glide rather than a long, sssentially straight glide as the Sterna tems do (Hoynihan, l962; pers. obs.). The high flight of Gygis is similar to that of the dark Iodizes (Hoyninan, 1962).

The low Pifight is poorly developed in fuscata and not nearly so comon as in other terns except Gygis (Do:-1ard, 1963). Cullen (1960a) notes that the low flight has fever special features and may have developed incependently in each species. The rarity of the low flight by fuscata may be due to its diperent manner of carrying food. Cullen (1960a) notes that food also has little importance in advertising by unmated birds of both scecies of Anous, both of which carry fcod in the esophagus as Sooties do.

Perhaps carrying fcod in the esophagus allows sooties to trancport more food (Ashmole and Ashmole, 1967) than if it were cerried in the bill. Also it may prevent food desiccation during the often lengthy return plight to the colony. The food is the major water source for the chicks, so moist food may be necessary for the chick's survival, Moist food should be easier to handie and swallow than driod-out food. Besicies Sooties, S. 2njetietus and both Anous cary tish in their esophagus.

The ground displats of Sooties seem similar to those reported for other Sterna terms, all having some form of a parade display. In particular the parade of Sooties seems to resemble that of the Cormon Iern described by palner (194i). Incipient scrapebuiluing activities are part of courtsinio in Sooties, just as they are in Comon Tenns (Pajner, I94i). 
The rost conspicuous ground disolay of the dark ioddies is nodding, and generally their behavior is gull-like (15ynihan, 1962). Nodding emphasizes head motements, whereas the parade emphasizes the position of the wings and head, providing a clear cnntrast between the Woddies and the Stema terns. The displays of Girzis are similar to those of the dark liodiles, but are verj simplified (Moynihan, 1962).

Compariscns of behavior help clarify the relaticnships of various terns. Moynihan (1959) used concarative behavion as a basis for classifying the Laridze and put ali tems into three genera. Larosterna remains monotypic, Anous includes Gyos and Procelsterna, and tile rest are placed in Sterno. I prefer the older teminciogy, retaining murerous genera, but nonetneless agree with the group limits he nas established on the basis of beharior. In Hoyninan's classification, the typical black-capoed tems include Euscata, himado, Daradisaea, and others. He puts the large Tha?assels terns and the smail Sterne terns like albifrons in separate groups within his large genus Stema and also keops the marsh terns (Chlidonias) together as a separate group within Sterna.

This grouping agrees weli with my observations, The high rlight of fuscata is almost iderical to that of hirundo and oaradisaes. The ground displays of fuscata are very similar to those of himindo and on behavioral grounds the two species clearly are closely related. In contrast the aisplays of Gyis and both species of Anous, three species that share the tropical oceans with sooties, are elearly cifferent from those of sroties.

Moyninan (1959) points out, and I agree, that a most profitable area for future work is with the many old world and tropical foms that 
are only slightly known. Two other tropical terns, Sterma lunata and anaethetus, resenble fuscata in their feeding habits and probably their breeding biology, although thoy may feed more offshore than pelagically. As yet these two are poorly kncm and further wcrk on then certainly would be of interest.

\section{Sooties as a Pelagic Species}

of the 40 spocies of tems (Sterninae), most feed either on freshwater marshea, lakes, and streams, or along marire coasts and estuaries. A few venture into offshore waters (on continental shelves or near islands), especially in the nonoreeding season. Sooty Tems seem to be the most pelagic (bejond the continental shelf) of terns, a? though several other Stema, both species of Anous, and Givis feed in offshore and pelagic waters. Apparenty by exploiting pelagic waters anc breeding on isolated islands, sooty Terns vitilize a nj.che available to few other species. Sooties are highly adapted to exploit this niche, particulariy in regard to slying ability, poplilation structure, and breeding biology.

Probably foremost among theis adaptations for exploiting pelagic waters is flying ability. Sooty Terns rapidly become waterlogged winen placed on water (Watson ard Lashiei, 1915) and apparently seldom rest on water. As Socties inhabit the open oceans during the nonbreeding season, birds from some colonies must fly continuously for 6 months or more. Virtually nothing is known of the physiological adaptations involved in flying for such long periods. For example, do they sleep on the wing as the swift (Apus 2uls) apparently does (Lack, 1956), or do they go without any sleep at all? 
anea far from land, reached by few other bjrds. Several factors restrict Sooty Tem food arailability. Except for scme areas where uprellings or convergences occuin, tropical pelagic waters are poor In mutrients and plankton that form the base of their food chain (Raymont, 1963). Sooties apparently are restricted to feeding on food itens that occur at, the very surface of the ocean, or in the air above it. This food is driven to the surface mainly by laige predacious fish (Ashmole and Ashmole, 196́7: 58) and thus is not evenly distributed throughout the ocear.

The length of incubation shifts and brooding spells varies considerably botween different Sooty Tem colonies. Adults usually shift at $I$ or 2 day intervals on Bush Key whereas they vary from 2 hours to 3 days in the Seychelles (Ridiey and Percy, 1958), and are as Iong as 6.5 days on Ascension Island (Ashmole, 1963), and 7 days on Christmas Island (Ashmole and Astmole, 1967). The duration of the shift rusi depend on the time required to fly to the feeding ground, find enough food to last until the adult can feed again, and then return to the colony. Uniortunately feeding rates and exact locations of feedine grounds for various colonies are not know. The nost, reasonable exolanation for the great variation between colonies in time spent foraging is that lood is farther aray or scarcer for some colonies than others.

Hore puzzing is the change in length of spells once the egg hatches and the chick must be fed. At Ascension Island adults change from 5.5-day-incubation sirifts to reeding their chick about once a day (fismole, 1963). As the breeding cycle at that colony is nonannul (9.5 months), it seens unlikely that a rezular change in abundance of 
food could occur and thus account for the differences in foraging between ircubation and fledring periods. On Bush Key adults change from 1 cis 2 diy inclibation shifts to feeding the chick several tines a day. As the breeding cycle there is annial, perhaps food is mor abundant, close: to the islind, or the adults forate more diligently when chicks are present. The meager eridence arailable indicates that terns do not tend to capture snaller fish ther they are Peecing chicks as might be expected (Fotthoff and Richards, 1970) but little is known acout the food sipply. is the parent forages not only for itself but also for the chick in a sinorter pericd of time, it probably works harder when feeding the chick then during incubation. Put another way, after sitting quietly on the egf for several days, adults probably loaf at least part of the tine curing breaks from incubation.

Table 8 gives some information on the breeding biology of sevexal representative tern species. I have selected one species each from the genera Chlidonies, Thalasseus, and Anous and only a few from Sterna, picking species for which information is availabie and that seen to be representative of other similar species. This table is similar to one in Lack (1968: 260). The patterns in Table 8 vary both betwen veriolis colonies of a. spesies and Prom year to year within a colory, but this does not negate the comparisons to be made here. The purpose of the table is to try io compare some general features of the breeding biology of marsh and coastal feeding terns with those that ieed offshore or pelasical?y.

On Busin Koy as at other Sooty Tern colonies, occasionally a scrare contains tro ezres, but by far the listal clutch is one egg. Sing?e egg clutches are common amone memine birds (inck, l,68) and seem to impli 


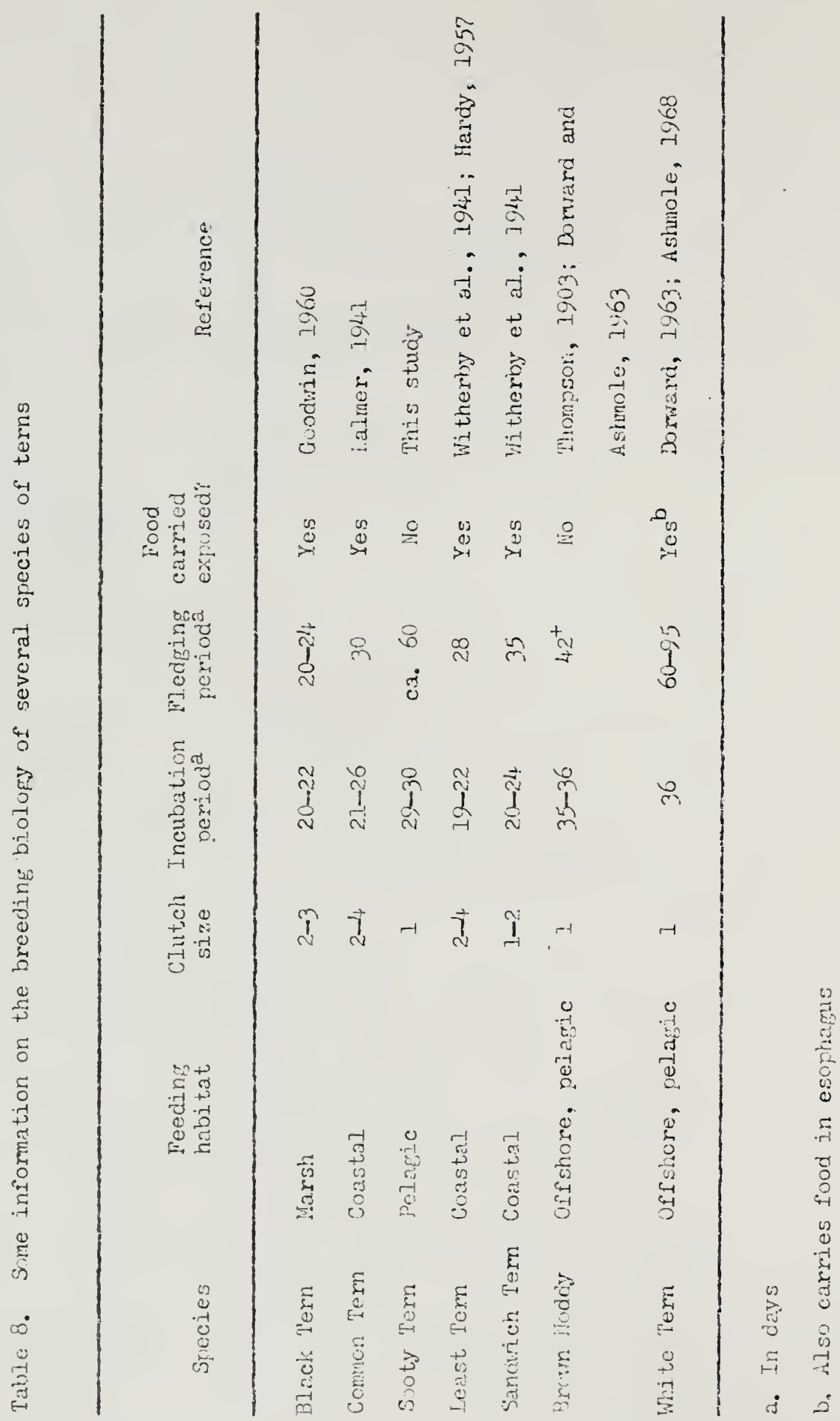


that something about the oceanic habitat limits their clutch size. In contrast, coastal and freshater feeding terns commonly lay more than one egg (Table 8). Besides fuscata, only Anous, Gyisis, and a fen otiner Sterra terns (e.g. S. araethetus and Junata) hare a nomal clutch of one. A clutch of two or more presurably is primitive in Sooties and Brown Noddies, as they both have tuo brood patches. Gyjis lays one ezg and has only a single brood patch, out its unusual nesting habit: may explain this (Dorward, 1963).

With the smaller clutch size, pelagic terns must have either a high nesting success, a long life span, or some combination of the two to maintain their populetions. With a clutch of one, partial nesting success does not exist. Fither they fledge a young or they fail. fmong Scoties, a naxinum of 50 per cent renest if the first atterpt fails and the percentage declines as the breeding seascn advances (Ridley and Percy, I958; Asimole, 1063).

The single egg of fuscata is incubated longer and the chick is cared for longer than are those of inshore feeding terns (Table 8). As Sooty Tern chicks may not be fed at regular intervals, a lengthened period of development probably allows them to withstand the occasional short periods of fasting (Lack, 1.968). Chicks grow rapidly when food is avilable, but can survive long periods without food if the adults cannot find any for several days (ishmole, 19,63). Storns and a distant food supply guarantee that short fasts occur regularly at some coloniss. Feeding rates also differ between Sooties and coastal feedinz tems. The latter generally forage close to their colony and, although they may raise more than one chick, they feed their young frequently. On the Fame Islands, Conmon, Arctic, and Bandwich Terns all feed each 
of their young abolt once ar hour (Pearson, 1968) and 3lack Terns feed young as oiten as 15 tines in an hour (Goodwin, 1960). As a result their young fledge mich faster than do young Sooties. The differences between Sooties and ioddies, both of which raise one chick per pair, havo already been discussed. Noddies forage closer to the colony, feed their young somewhat more frequently, and their young matire faster than the farther ranging Sooties (Table 8).

An important factor favoring the slow development of young Sooties is the scarcity of predators on islands where they breed. They can "afford" Iong incubation and fleriging periods without drastically raising the risk of predation. Common and Least Terns nesting on or close to the mainland are constantly exposed to predation (Austin, 1948; Hardy, 1957) so it is probably advantageous for them to raise their young as quickly as possible. In turn rapid growth of their young is made possible by a food source close to the colony that permits more feeding trios in a day. Cat predation on Ascension Island shows vividly what can happen to seabirds, including Sooties, when a land predator is introduced (Stonehouse, 1962; ishmole, 1963).

Sooty Terns defecate near their egg, do not always remove the empty egg sheil, and nest in dense colonies. These habits seem related to the isolated and usually land-marmal-free islands where they nest. Sandwich Terns have similar habits, but frequently nest with gulls that helo drive off intruders (Cullen, I9500). In contrast, Arctic and Conmon Terns cary off the cmpty egs shell, defecate away from the nest, space their nest.s farther apart, and vigorously attack intruders, all of which should help reduce predation. Comnon and Arctic Terns also have much shorter incubation and fledging pericds than Sooties, 
again reducing the time they are mlnerabie to predation.

With all tine problems that Sooties enccunter in! feeding far from their nesting colony, they still are very plentiful. Obviously the number of islards, slitable for nesting, within theï range is finite. On some islands marl has greatly reduced tern numbers, either by egging (Ridley and Percy, 1958), or by introducing predators (hshrole, 1963).

Sooty Tems probably do not first breed until 6 years old (Robertson, 1969) whareas most Comor Terns first breed when 3 or 4 years old (Austin and Austin, 1956). Delayed maturity occurs in many other seabirus, incluiing many Larids (iack, 1968). Robertscn (1969) suggests that the transatiantic migration by jurenile sooties from Bush hey, a colony relatively stable in numbers, keeps theri from competing with oider and presumably more efficient breeders for sejeral years. The 3-rear-old birds that visit Bush Fey Iate in the breeding season have little chance of finding a suitable nest site and breeding successfuliy. By returninz to the colony earlier in successive years, eventual?y they should be able to arrive early enough to find a suitable nest. sizte and breed successfuliy. Thus delayed maturity keeps younger birds from conpeting with older, esteblished breeciers for rest sites, and also keeps the younger birds from undergoing the rigors of reprociuction until they have a fairly high probability nf success. The Fishers (1069) note a staggered arrival ci age eroups of Iaysan Albatrosses, with the young birds not breecing for severaI years.

For deleyad returity to persist, individuals with sich raturity must rajes more ofspring in the long run than if they first bred 
when yourger. Is some 3C-yean-old Scoty Terns are presently on Bush Key, the adults there cieariy have wany breeding opportunities. Still Sooty Ierns, by delayinz breeding for several years and then by raisins at most a sirgle young per breeding season, have a lowar maxnum natality than other similar tems that feed close to their colony.

Lack (1968) proposes that birois raice as many offspring as possible with the usual clutch size being that that results in the nost. breeding aduits in the next generation. According to his ideas, Sooty Terrs with a clutch size of one cannct raise more than one young per breeding season. Presumably the liniting factor is their distant and sonetines unreliable food supply.

Certainl the hroothesis lits the information from fscension Island where an acparent failure of the food supply one seascn resulted in few chichs surviving (Ashmole, 1963). This and the long spells that Aseansion acults speno foraging suggest thet at nost a pair could raise one chich. Other colcnies that have ceen studied hate not had such failures.

Except for the cats on Ascension Island, adult Sooty Terns suffer Iittle predation and have a Icu armal adnlt nortality, pernacs around 12 to 18 per cent at Blish Key (Austin, pers. ccmm。), versus 25 per cent in aduit Comon Tems (astin and sustin, 1956). Although the food supply ray limit the numbers of young they can raise and hence detemine the usual clutcin size of Sooty Terns, pernaps delayed maturity is a function of the los predation on and high survivorship of the adults. High survirorsiz of adults could result in many birós competing for a limited number ci nest sites, but cielajod maturitj 
could reduce this competition as has alreacy been discussec.

Sone pelagic species can raise more than one young ( see Harris, I970), indicating that food is not entizely Iimiting, but so far the problem has been followng the surival of these "twins" until tivey returit to iread.

Thus Sooty Terrs affer from nost other tems. Many of these differences derive from their adattations to a pelagic environment. The basic beiterisoral patterns in pair formation ard courtship shcw clearly that sooties are closeiy related to typical Sterna tems such as himuncio.

I beliewe sereral behavioral aifierences between Scoties and most other suecies cf Sterra are due to their different way of carring food. Sooties do not have a well-developed lon Ilight àsplay, a display in ming other tems often proninently carw a fisin in their bi11. Other tems also may carry a fisi openly in the bill during the high flight while booties do not, although they do have a relldeveloped high Plight.

The high cost of ootaining iood, compared to that of coastral fesuing tems, pernaps explains my courtsip feecing is relatively rare in Sooty licrns. A coastal feeding tern oan easily repiace the food it iescis to anotiner bird in courtship. For a Scoty Tern, replacenent rould requirs a long flicht.

Comparison of the oreeding biology of Sooties and coastal feeding temis shous other differonees. The development of the Sooty Tern egs and chick is mon slower than that of most other tems, probaing so their ycune car surrive I engthy periods when the parents ane unable to find food. The high simivorsizp of adilts and the distant food 
suppiy have led to their delayed ratur.ty and small clutch size.

Thus in their breeding biology, with a long incubation and fledging period, delayed maturity, and a onemegralutoh, Sooty Terns resemble other pelagic birds such as the albatrosses, shearwaters, and tropicoirds more cicsely than most other terns. 
Ashrole, $x_{m}=2063$. The biciog of the Wideawake or Sooty Ferm

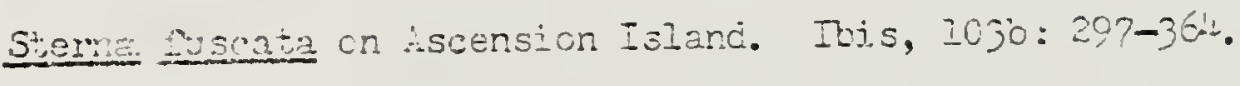

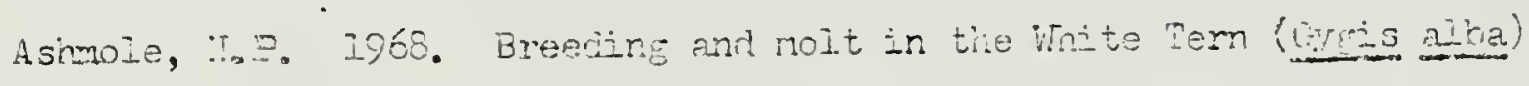

on Chrastuas Isiand, Pacjefic Ceean. Condior, 70:35-55. Ashmole, N. I. anci... J. Asinole. 1967. Comparative ieedins ecology of sea dris of a troptical oceanic island. Eull. Feabody ins. iat. HE. $24: I-I 3 I$.

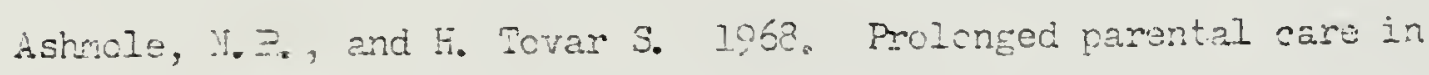
Royai Tems and other birds. Auk, 85:90-i00. Audubon, J.c. 184. The biras of America, vol. \% 1967 reprizt. Iex Yout, Dover Dubl., Inc. Austin, c. In 1948. Predation by the comon rat (Rattus ncruestons) in the Gape Cod colonies of nesting terns. Bird-Eandirg, 1.9: $60-055$. Austin, 0. Is 1949. Site tenacity, a behaviour trait of the Comon Tern (Stome himeno Iinn.). Birt-3enuirg, $20: 1-39$. Austin, 0.I. 2951. Group äherence in the Comon Term. Birci-3:xising, 22:1-15. Austin, O.I. End O.I. Austin, Jr. 1956. Sme demograritic ascects cf the vene Cod ropulaticn of Comnor. Ferms (Sterma niminio). Birri-2anding, 27: 55-56.

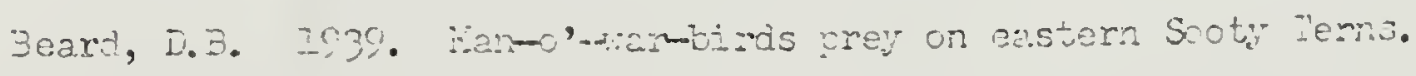
Auk, 5ि: $32 \%-32 \%$. 


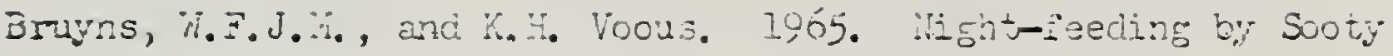

Terms (Sterra fuscata). Árdea, 53:79.

Burchiater, D. I. IG6g. Orientation anc commication of Sooty Ferm

chicks, it. S, thesis. Zuscon, Amzona, unì, of Arizcna.

Chaoir, J.F. 1954. The calendar of nideatrake Sair. Auk, 7l: 1-15.

Cott, 4.3. 1954. The expioitation of rild birds for their eggs.

Ibis, 96: 129-14:0.

Cullen, J.M. Ig60a. The aerial display of the Arctic Tem and other speries. Arciea, $48: 1-37$.

Culien, i.M. I960b. Some adaptations in the nesting vehaviour of tems. Froc. 12th Intern. Omithol. Congr., 153-157.

Culien, J.A., ano. ‥P. Ashmole. 1963. The Black iodidy dnows

tenuinesticis on hscension Islanci. Part 2. Behavicur. Ibis, 203b: 122z-44ó.

Cunningham, P. L. 2965. Fredation on birs by the Cattle Egret. Ank, 82: 502--503.

Davies, S.J.J.F., and P Carrich. 196́2. On the abiizty of Crested Terms, Stome berriz, to recognize their cwn chicks. Australian i. 2007., $20: 171-177$.

Dorward, D.F. 1963. The Faing Tern Gyis 21ba cn kscension Island. zois, $1030: 365-378$.

Dorvard, D.F., and I.P. s.sin:ale. 19,63. liotes on the biology of the Brom Jodiry fnous stolidus on Ascension Island. Ibis, 203b: $447-2+57$.

IreIIman, I. $I_{*}$, and A. Schwart.. 1958. Amohioians and reptiles of

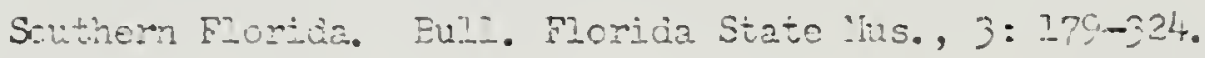
Excman, J.S. 196\%. Eea binds in relatich to gane fish schools of 
Duerto Rico and the Virgin Elands. Caribbaan J. Sii., 7: 7,-35. Fisher, H. ., and I. L. Fisher. 16.69. The visits oi luaser.

Albatrosses to the breeding colcny. Wicronesica, 5: 173-221. Goodritn, R. I I960. A study of the ethology of tre Zlack Tem, Chlideries nion sumingersis (Gmelin). H. D. thesis. Ithaca, New York, Comelí liniv.

Goula, P.j. I9ó7. Vocturnal feecing of Sterma fuscata and Elffimus nacifinus. Condor, $69: 52 \%$

Haray, J.i. I957. The Iseast Tem in the libsissippi Valiey. Mibl. Ius. Zichigan State iniv. Điol. Series, I: I-60. Harris, … I970. Ereeding ecology of the Siallotitajied GuII, Crearins surcatixs. ink, $87: 275-243$. Harrison, C.J.0. 1965. "Stare-down" in birds, and its apverent function, inder, $53: 57-72$. Hatch, J.J. 197C. Emeciation and piracy by guils at a temeny in liaine. $\quad$ arit, $87: 24-254$. Fowell, T.P., and G.A. Bartholomer. 2962. Temperature regulation in the Sooty Tem Sieme. Iuscati. Ibis, 104: $98-i 05$. Futchison, DE. J.G. Stevenson, and W. I. Thore. 2968. The basis Aor Indiridual reconzition or vojce in the Sancirich Tern (Stema sendvicensis). Behaviour, 32: 150-i5?.

Iredais, T. I0I4. On Stema Iuscata Linne'. Ibis, $56: 436$ 437.

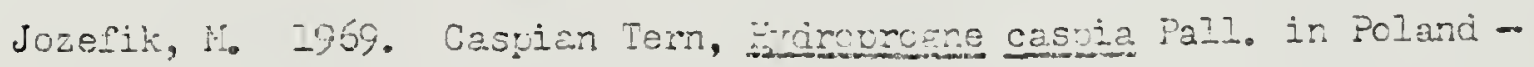
the bioiogr of migration portoc. Acta Crmitinol., Il: 3zI-4tit?. Lack, D. 1956. Sufits in a towe... Iondon, Hetiuen and Co. Ito.

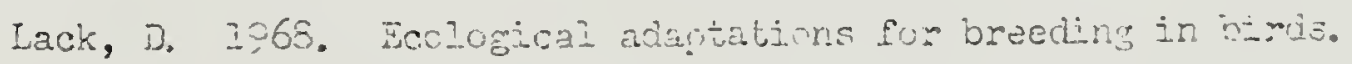
Londor, wetivuen anci Co. ithl. 
Lashley, K.S. 1915. Notes on the nesting activities of the lloddy and Sooty Terns. Camezie Inst. Washington, Papers from the Dept. Vierine Biol. s 7: 6i-s3.

Iongley; W... 1929. Observations on Tortugas físhes, escecialiy those on whin the Noddy and Scoty Terns of the Bird key rookery feed. Camegie Inst, Washington. Yearbook, 23: 28E-290.

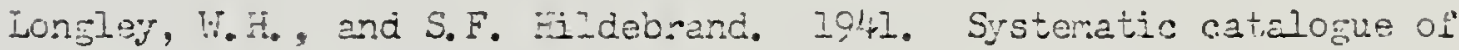
the fishes of Tortugas, Florida, th observatzons on color, habits and local distribution. Camegie Inst. Wasininton, Fapers from Tortigas Laboratories, $34: 1-331$. Wason, C.R. and …D. Stefzee. 1966. Banding party vaits out Alra. Floricia naturaist, $39: 147-248$. Wonroe, B.I., Jr. 1955. Osservations of Elegant Tern at San Iiego,

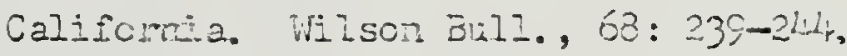

Noynihan, i, 1959. A revision of the family Lariciae (Aves). Aner. Mus. Novitates, 2929: I- +2 . Moynihan, 1. 1962. Fostile and sexual behavior pattems of Bouth Americen and Facilic Laridae. Behav. Suppl., 8: 1-365. Painer, R. S. I24]. A benavior study of the Cormon Iern (Sterna hirunjo semindo I.). Proc. 3oston Soc. Nat. Histo, 42: I-129. Pearson, T. 1968. The reeding biolong of seambirl species breeding on the Farne Islands, Northumberland. J. Arim. Ecol., $37: 521-552$. Potthoff, I.: and U.R. Richards. I970. Juvenile bluefin tuna, Thunnus inmmus (Iinnaeus), and other scomorids taken by tems In the Dry Tortugas, For:ida. Buj. Narine Sci., 20: 25s-mi3. Faymont, J.E.G. 2663. Fiankton and productivity in the ccears. New Yori, Mamiliar, Co. 


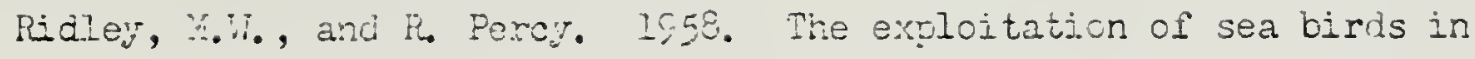

Seychelles. Coionial Researcil Studies, 25: 1-78. Robertson, W.B., Jr. 1962. Florida region. Audubon Field Notes, 16: $468-473$.

Robertson, H.B., Jr. 1964. The tems of the Dry Tortugas. Bull. Florida State :us, , 8: i-gh。

Robertson, W. 3., ir. 1969. Transatlantic migration of juvenile

Soty Terns. Nature, 222: 632-6́34:

Farscel?, J.C. 1938. Narrative report on wildlife of Fort Jefferson National Monument. Unnublished report, National Park Service files.

Sprunt, $\lambda_{0}, \mathrm{Jr}$. 1948. The tern colonies of the Dry Tortugas Kevs. Auk, $65: 1-19$.

Stonehouse: 3. 1962. Ascension Island and the British Omithologists' Union Centenary Expecition 1957-59. Iois, 1036: 107-123. Thompson; J. 1903. The Tortigas tem colony. Bird-Lore, 5: 77-34. Tinbergen, N., G.J. Broekhuysen, F. Feekes, J.C.i. Koughton, K. Kruuk, and $\Xi$. Szulc. 1962. Egg shell removal by the Black-headed Guil, Iems rididundus I.; A behaviour component of camouflage. Benatiour, 19: 74-117.

Tompkins, I. $R_{0}$ J.g42. Least Tem watering eggs: Gideon labbett's query. Ank, 59: 308.

Vaughen, T.1. 2918. The tomperature of the Florida corai-reef tract. Camnegie Inst. Washington, Pavers from the Dept. Warine Biol., 9: 319-339.

Watson, J.B. 10,08. The behavior of Hoddy and Sooty Tems, Camegie Inst. Washington, Papers from the Tortugas Iaboratory, 2: 187-255. 
Watsor, J.3., and K. S. Lasiley. 1915. An historical and experimental study of homing. Camegie Inst. Washington, Papers from the Lept. Harine B:01., 7: 7-60.

Witneroy, H. .., F.C.R. Jourdain, N.F. Ticehurst, and B. H. Tucker. 1941. The handbock of Eritisin birds, vol. 5. Iondon, H. F. and G. Witherioy Itd. 
Jaries Jay Uirsmore was born 25 February 1942 at Owatoma, itinnesota. In June, 1950, he graduated from Owatorna ت̈in School. He enrolled at Iowe State University and in lay, 1964, recedred the Bachelor of Eciance degree with a major in Fish and Widife Haigement, He ther enrolled at the University of Hisconsin, Iadison. Fron 1965 to 1966 he lived in Tobago, West Indies doing Pield work and in August, 19,67, received the Waster of Science degree with a mor in Zoology. In September, 1057, he emplied at the University of Plorida and began work on the Doctor of Fhilosophy degree. At Fuoride he held a Graduatc Ehool Fellowship and later worked as s crraduate teaching assistant, first in the Departient of Z00log: and then in the Department of Biological Sciences. From 1969 to 1970 he heid as apoointnent as Interim Instructor in Biological Sciences.

James is marked to the forme- Patricia Ann Hoops, and they have two sons. He is a merber of the imericen Ornithologists' 'Jnicr, Cooner Omithological Society, Wilson Omithological Society. Stgna Xi, and Phi Kaova Phi. 
June dissertation was prepared andes" the direction of the chan man ul the candidate's supervisor committee and has been approved by ait members of that committee. It was submitted to the Jar ci the College of Ax ts and sciences and to the Graduate Council, and was approved as partial fulfillment of the reguicmerts for the degrees of Doctor of Enicsoping.

ALErt, 1970

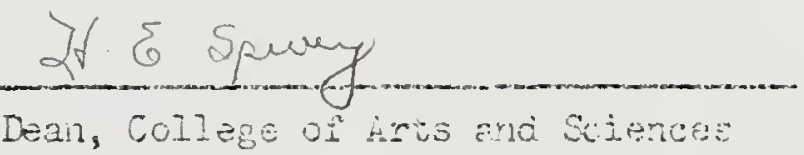
Dean, Graduate School

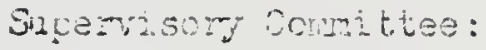
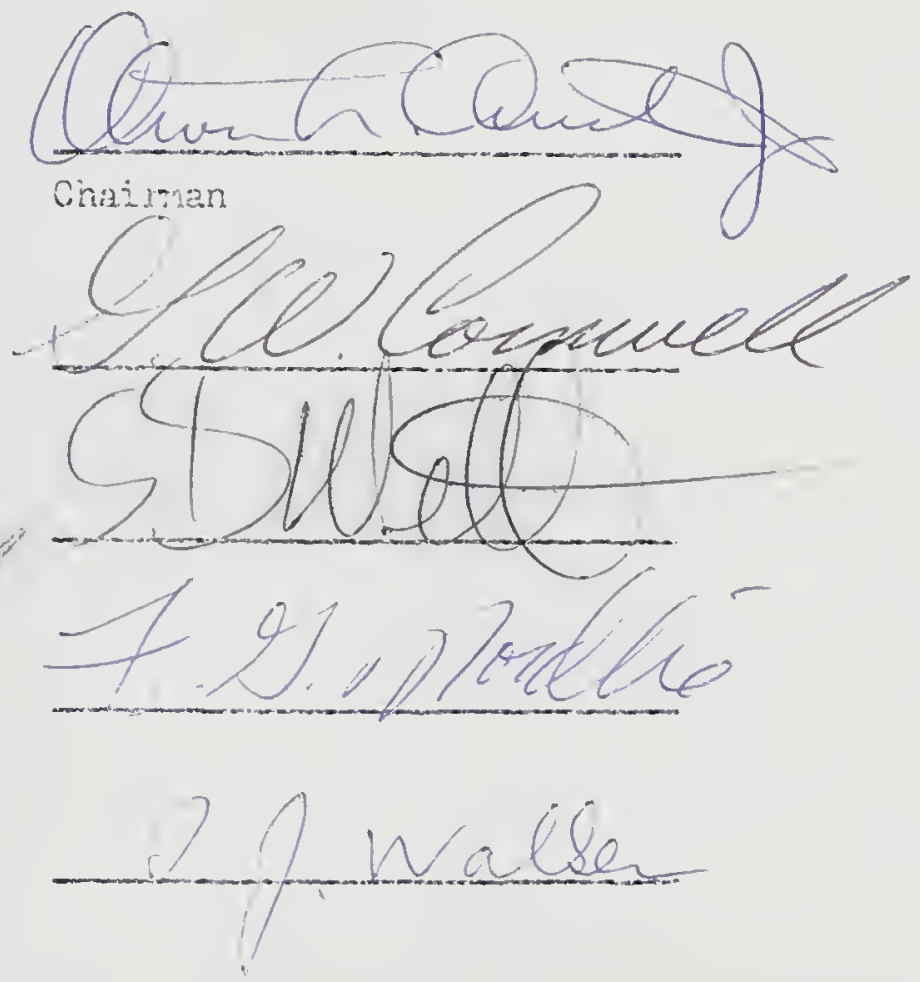

Jalue?

n. 